European journal of American studies

Summer 2015, including Special Issue: (Re)visioning America in the Graphic Novel

\title{
Migratory Subjectivity in E. Jane Gay's Choup-nit-ki, With the Nez Percés
}

\section{Wendy Harding}

\section{(2) OpenEdition \\ Journals}

Electronic version

URL: https://journals.openedition.org/ejas/11038

DOI: 10.4000/ejas. 11038

ISSN: 1991-9336

Publisher

European Association for American Studies

Electronic reference

Wendy Harding, "Migratory Subjectivity in E. Jane Gay's Choup-nit-ki, With the Nez Percés", European journal of American studies [Online], 10-2 | 2015, document 11, Online since 14 August 2015, connection on 08 July 2021. URL: http://journals.openedition.org/ejas/11038 ; DOI: https://doi.org/ 10.4000/ejas. 11038

This text was automatically generated on 8 July 2021.

Creative Commons License 


\title{
Migratory Subjectivity in E. Jane Gay's Choup-nit-ki, With the Nez Percés
}

\author{
Wendy Harding
}

\section{Introduction}

1 In 1889 two women alighted from the palace car of a West bound train and surveyed the squalor of the hastily constructed town of Unionville, Idaho. Alice Fletcher was there to assign allotments of land to members of the Nez Perce tribe under the provisions of the Dawes Severalty Act of $1887 .{ }^{i}$ Her companion, E. Jane Gay, was there unofficially, having failed to obtain a government appointment as the party's photographer. Besides tending to Fletcher's domestic arrangements and keeping up correspondence with family and friends back East, Gay made photographic records of

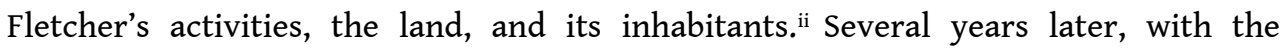
collaboration of her niece, Emma Gay, E. Jane Gay compiled a selection of her correspondence and photographs into an epistolary memoir entitled Choup-nit-ki: With the Nez Percés.iii In gathering into book form the discourses and images she produced in response to her encounter with the Nez Perce, the writer stages herself as a subject divided by the contradictions inherent in her situation. Innovative features like the shifting focalization, the splitting of the writing subject into multiple personae, and the comedy of contradictions challenge conventions governing genre and gender and destabilize the fiction of unitary identity on which life writing is traditionally based.iv Thanks to the challenge to binary structures issued by feminist, queer, post-colonial, and post-structuralist critiques, readers now have the means to appreciate Gay's innovative contribution to the genre. Her hand-crafted book stitches together a protonomadic subject almost a century before Deleuze and Guattari or Braidotti theorized the concept. This daring experiment in life writing covers a watershed period in the author's existence and documents her struggle to come to terms with the conflicts arising from her implication in the imperial enterprise of settling the American West. 
2 Changing places can have contrary effects on travelers. On the one hand, experiencing unfamiliar localities and peoples may confirm cultural preconceptions; on the other, witnessing different modes of existence may expand frames of reference. Gay came to Idaho with fairly conventional ideas about the existence of distinct racial categories that upheld Euroamerican superiority. Some of the remarks in her book demonstrate her belief that Indians could only progress by adopting the white man's way of life. Nevertheless, some of Gay's experiences in Idaho challenged those assumptions and upset her aspiration to document the advance of Euroamerican civilization.

3 Her companion's work as Allotting Agent was part of the broader policy of assimilating Native Americans into the nation or "civilizing" them according to the ideology of the time. Issuing from the Progressive Movement, the Dawes Act aimed to transform tribe members into independent individuals who would be responsible for their own wellbeing. It proposed to supply every Indian family with sufficient land to sustain itself. Nonetheless, by abolishing the reservations, the Dawes Act further despoiled Native Americans of their already diminished territory and made much of it available to homesteaders: "Allotment decimated Native lands" (Tonkovich Allotment 8). Ironically, while Fletcher labored to break indigenous cultural patterns, she also worked on documenting them, taking a major role in the new field of Anthropology. ${ }^{v}$ Gay, in turn, documented Fletcher's activity, ${ }^{\mathrm{vi}}$ as well as observing, photographing and commenting on events on the Nez Perce reservation and representing her own response to the challenges issued by the experience.

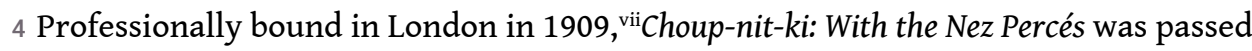
down to Gay's family and then donated to Radcliffe College in 1951. In 1981 Frederick E. Hoxie and Joan T. Mark edited an abridged version of Jane Gay's work. They dropped the words Choup-nit-ki from the title, renaming the book With the Nez Perces: Alice Fletcher in the Field 1889-1892. That new title suggests that the book is a memoir about Fletcher rather than being Gay's literary response to her personal experience in Idaho. The editors' selections from the letters emphasize the book's historical interest; a number of the more quirky personal reflections have been cut. Only the unexpurgated version-fortunately now available online-gives a proper sense of the author's originality. Because of its unusual publication history, Gay's book has not received the critical attention it merits. . vii 


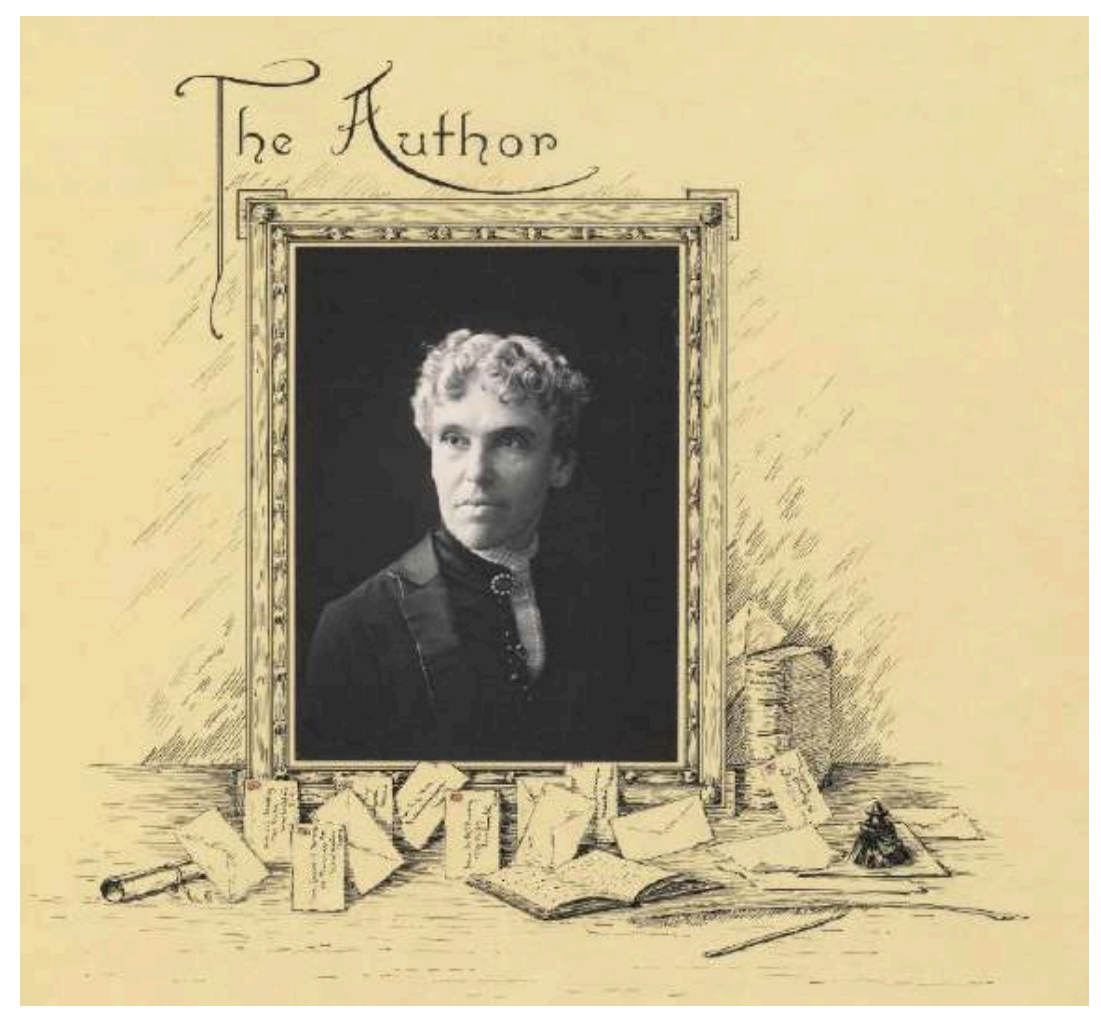

Choup-nit-ki's paratext sets up certain expectations that the text goes on to disturb. ${ }^{\mathrm{ix}}$ On the spines of the two-volume, leather-bound book, underneath the title, embossed in gold, the name E. Jane Gay appears. Centered on the first page, under the heading "The Author," we find Gay's photograph, surrounded by an ink-drawn frame (Gay 1909 i). ${ }^{x}$ Under this frame, the illustrator, Gay's niece, ${ }^{x i}$ has drawn various objects that picture the writing process-a quill pen and inkwell, an open journal, a book, and scattered letters enclosed in stamped envelopes. This signature seems to establish what LeJeune terms the "autobiographical pact"-the convention that centers the text on the individual identified as its author. Readers will assume that the text is one of those travel memoirs relating a woman's singular experience in the American West. Bearing in mind modern notions of the self, ${ }^{\text {xii }}$ we would expect this persona to present herself as a unified entity whose experiences illustrate continuity as well as growth. Yet this is not what we find in Choup-nit-ki.

From the title page the author troubles her identity by naming herself $E$. Jane Gay or "Gynx" (iii), the mischievous-sounding nickname doubling the more ponderous monosyllabic triplet. Rather than finding a consistent, authoritative, unitary individual speaking of and for herself, we discover a fragmentary, ambivalent, polyvocal narration. Gay could have reworked her letters into a smoother, more unified narrative; instead, she draws attention to the book's heterogeneous scrapbook form by numbering and dating each letter, identifying its place of origin, and including the initial of the original addressee. Just as she sutures together these epistolary fragments, allowing the seams to show, Gay constructs a protean narrator who mocks the illusion of unitary identity and instead revels in multiplicity. Her montage of letters and photographs presents a composite, porous self that undermines the ideological constructs of American individualism that were being relayed by the various agents engaged in the nation's imperial enterprise, including Gay herself. 


\section{Opening to Other Voices and Other Views}

7 In the genres of letter-writing and personal memoir, the writing subject conventionally asserts her identity and claims the authority accorded to experience by using the first-person pronoun consistently. In Choup-nit-ki, by contrast, the use of pronouns is unstable, often directing attention away from the writing subject and allowing other voices and points of view to enter a text that makes dialogism a prominent feature of its style. ${ }^{\text {xii }}$ Readers of the book's two volumes need to become accustomed to the instability of the narrative voice; it is one of the most striking features of Gay's writing, and it cannot be explained simply by the fact that her letters are addressed to different correspondents.

8 The writer's self-fragmentation begins in the "Prefatory Note," where an impersonal, official-sounding voice briefly chronicles the events that led Fletcher and Gay to travel to the Nez Perce reservation: "To those not conversant with Government legislation in regard to the aborigines of our country, it may be well to say that after narrowing the tribal lands to the extreme limit of prudence, and it began to look as if the ever encroaching white man would 'take' all that was then left, Congress, on February $8^{\text {th }}, 1887$, passed the Land in Severalty Act, commonly called the Dawes Bill" (vi). In this preface Gay addresses general readers whose knowledge of historical circumstances cannot be assumed, an audience other than the addressees of the original letters. She introduces Alice Fletcher as one of the Special Agents appointed to carry out the allotment of lands before finally referring to herself in the third person and identifying herself as "an unofficial member of her party" and as "the compiler" of the collection. The preface merits an attentive reading. The writer's oblique positioning and official sounding tone mimic the rhetorical devices that create the illusion of objectivity. In fact, Gay parodies official discourse in order to ironize about the systematic dispossession of American Indians by "the encroaching white man." The latest episode in that history, the one that Alice Fletcher was appointed to oversee, is presented as a way to halt the encroachment; nevertheless, Choup-nit-ki reveals Gay's skepticism about the new development, even as it shows her involvement in the implementation of the Allotment policy. In her letters she wavers between confidence in Western civilization and skepticism about the virtue of its representatives in the American West. Like a number of women writing from the frontier, she is ambivalent about her nation's imperial enterprise. ${ }^{\text {iv }}$ What makes Gay exceptional is her discovery of an innovative mode of composition to express that ambivalence.

9 Gay's consciousness of her dividedness is paired with her capacity to imagine other points of view. She is able, at times, to move away from the confines of her positioning as a fairly privileged, educated white woman and to consider categories of race, class and gender ironically, without, of course, ever being able to escape them. Gay's wry detachment comes across in her very revealing response to Franz Boas's request for biometric data on the Nez Perce. F.W. Putnam wanted to chart the statistics for display at the World's Columbian Exposition, and he assigned Boas to organize the data collection. Alice Fletcher therefore received a circular outlining the procedures for measuring the Indians' physiological characteristics and a questionnaire for recording their racial heritage. It was Gay rather than Fletcher who got involved in the procedures, and "as a lark, [she] filled out one of Boas's forms with her own vital statistics" (Tonkovich Allotment 188-89). Mocking the racializing logic of 
anthropology, ${ }^{\mathrm{xv}}$ Gay charted her own mixed heritage, identifying her father as "Jeshuran" (a man of God and a patriarch?xvi) and her mother as a "Highlander." The Scottish Highlanders were dispossessed of their dwellings in the eighteenth and early nineteenth centuries in order to make the land yield greater profit, and many

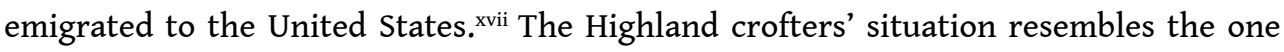
the Nez Perce were facing in that it disrupted traditional clan structures and denied the principle of common land. To categorize her "mode of life," Gay answers that she is "migratory" (Tonkovich Allotment 189). Without a profession during the time she is in Idaho, unmarried and without full citizenship in her own country, ${ }^{\text {xviii }}$ Gay is "migratory" in her way of life, but also, I would argue, in her subjectivity.

10 Gay's playful auto-analysis suggests a versatile, relational sense of self that prefigures some of the qualities that Braidotti associates with nomadic subjectivity. Gay's writing opens a space for a new construction of identity that allows "a play of multiple, fractured aspects of the self; it is relational, in that it requires a bond to the 'other'; it is retrospective, in that it is fixed through memories and recollections, in a genealogical process" (Braidotti 166). Aware of the relativity and provisionality of her positioning, Gay fashions a transgressive narrative voice capable of making connections across the cultural boundary lines demarcating categories of race and gender.

11 One of the ways she deviates from social and literary norms is in her use of pronouns. In a passage from Letter Three relating the women's first experience of a Nez Perce council, Gay begins in the first person: "When I last wrote, we were expecting the Indians to meet us in council the coming Monday" (35). However, she quickly adopts the second person pronoun and shifts to the present tense, setting the stage for the drama that unfolds at this first official contact with the tribe, and inviting readers to imagine themselves as witnesses: "Put yourself in the place. It is a hot day and there is not a cloud to break the force of the midday sun as you leave your quarters to cross the campus" (36). In an expanding series of potential addressees, the "you" indicates first the original recipient of the letter, Captain Pratt, former military campaigner in the Indian wars and founder of the Carlisle Indian School, then, the readers of the school's newspaper Red Man, ${ }^{\mathrm{xix}}$ where some of Gay's letters were first published, and finally the readers of Choup-nit-ki. Nevertheless, the identity of the "you" is far from stable; Gay employs grammatical shifters to summon an ever-changing cast of actors to perform in the scenes her letters evoke. ${ }^{\mathrm{xx}}$

12 In setting the stage for the first encounter with the Nez Perce, the writer creates a sense of suspense by describing a leisurely walk toward the site of the meeting: "In your path there is a young robin, fallen from its nest, and you pick it up and place it carefully in the shade of the house. The grasshoppers spring up under your feet and you catch one and put it into the beak of the orphaned bird, and then pass on through the open door" (36). These details are so precise that the pronoun apparently indicates neither the letter's addressee nor its more general readers, but someone-one would presume either Gay or Fletcher-who had actually taken the path herself. At the same time, the second person pronoun blurs distinctions between the writer, the protagonist in the scene, and the readers, encouraging us to become porous and to share the speaker's shifting subjectivity. The animals that the "you" encounters on the path do not simply add a touch of naturalism to the scene. Like many of the animal stories in Gay's letters this mention of the robin and the grasshopper can also be read 
allegorically. The anecdote illustrates the maternalistic solicitude (and condescension) that motivates the two women in their dealings with the Nez Perce. ${ }^{\mathrm{xx}}$ As the "you" enters the meeting place and contemplates the assembled tribal representatives, the identity of the actor in the scene becomes more definite; she could only be Alice Fletcher, and from her perspective, the Indians appear alien, not quite human:

There is tangible silence within; dark forms are ranged against the walls, some on wooden benches, others standing, and some prone on the floor.... You read the Severalty Act and explain its provisions. You think you make it plain but the rows of old red sandstone sphinxes make no sign. Their eyes are fixed in stony dumbness. They never heard of the 'Dawes Bill'; they cannot take it in. (36)

This account of the first meeting projects onto the Nez Perce the physical peculiarities of the racial other; they are seen as "dark forms" or "old red sandstone sphinxes." Indeed, "ranged against the walls" like furniture, they seem more like objects than subjects.

14 Almost imperceptibly though, the angle of vision changes and the racial stereotypes are overturned as the "you" morphs into the suspicious listeners who are certain of their right to their land: "Imagine your self, some bright May morning.... Before you lie broad acres, your own well tilled fields, that were your fathers' before you. They have been in the family for many generations; so long that it has never come into your mind that they could ever be anywhere else" (36). The scene Gay narrates is no longer geographically set in Idaho or historically fixed in 1889; it floats in some middle ground between there and elsewhere. The "you" even resembles the archetypal American farmer. This similarity increases as Gay introduces a new interlocutor who seeks to gain the proprietor's confidence:

You are awakened by the slam of the front gate and the lightning-rod man or a book agent comes round the house and tells you that the Empress of all the Indies, or some other potentate with whom you have treaty relations, has sent him to divide your lands according to act of Parliament, in the year of our Lord, February 8th, 1887.

You stare wildly while the lightning-rod man proceeds to explain that, as head of the family, you are to have 160 acres of your own land; your boy Tom, being over eighteen will have 80 acres; and the little girl, the pet, the black-eyed darling, she will have 40 acres. (36-37)

The "you" has become a composite of a cautious Yankee, alert to the confidence tricks of travelling salesmen, ${ }^{x x i}$ a Nez Perce, rightly suspicious of the imperialistic policy that aims to divide and diminish his or her land, and a Scottish croft-dweller despoiled in the Highland Clearances. In creating this hybrid victim, Gay implicitly critiques the imperialistic thrust of the Allotment policy. The connection she habitually makes between Alice Fletcher and Queen Victoria is not simply physical; seen through the eyes of the Indians, the matronly Fletcher might have looked like a tyrannical colonial potentate.

16 In the course of this single letter, the point of view slides from Gay, to Fletcher, to the Nez Perce Indians. At the same time, the second person pronoun inevitably places readers in the scenes narrated, inviting us to share the different emotions experienced by the actors. Thanks to Gay's use of shifters, readers reallocate identities and sympathies; we move from viewing the Indians as aliens, to embracing their vision of the situation. This is not the kind of masquerade that Deloria analyzes in Playing Indian, in which whites affirm themselves as Americans in appropriating elements of 
indigenous culture. Instead it is an exercise in empathy that springs from the writer's multiple, conflicting identifications.

17 Readers of the two volumes of Choup-nit-ki will initially find its dispersed, heteroglossic narrative voice bewildering.xxii It works to expand the writing subject and to crack the mold of Euro-American individualism. Identity becomes multiple, changing to adapt to different situations. This enlargement of the self might be seen as simply a further development of the imperial subject. Indeed, Romantic individualism and American expansionism converge in the well-worn trope of moving westward toward the future and freedom. ${ }^{\text {xxiv }}$ In the book's opening description of crossing of the Great Divide and arriving in Idaho, Gay places herself on the cusp of a new form of existence: "I began to feel as if I had already a new lease of life in this open, free land of breath and sun" (1). This declaration might be a prelude to a narrative of self-actualization and a claim to entitlement to write about the self. Nonetheless, the writer reverts to the impersonal mode, evading the imperial subject position through the use of modals and shifters: "It is superb, wonderful, and makes one wish he could begin all over again and work out a new term of existence, wider from the very start" (1). In invoking delegates, in this case, the generic "one" and "he," the writer backs off from the enlarged, affirmed subjectivity that readers may have anticipated and instead, wistfully yearns for a different form of being that has yet to be imagined. Choup-nit-ki invents a wider and more diffuse form of subjectivity by multiplying and diffracting identity through different forms of identification and projection.

\section{Splitting the Self}

18Rather than confirming Gay's agency and autonomy as a representative of American imperialism, the experience in Idaho disturbs her construction of self. The absence of recognizable cultural landmarks destabilizes the writing subject: "Well, my dear J., here we are and it is lonesome, it is queer, and the longer we stay, the queerer it grows.... There is no fulcrum whereon to rest a lever, no reliable data to be found" (27). This "queer[ing]" of the setting provokes a reconsideration of established norms. The experience in Idaho disturbs the scientifically founded convictions (the "fulcrum" and the "reliable data") that support Euroamerican dominance. With the dissolution of her certainties about the racial other, Gay's position becomes shaky: "But there sits Her Majesty, calmly writing, a placidity about her that is aggravating. She has come so near the heart of the Universe that she can rest content in the stillness of the centre of it all, while I, on the outer edge, am whirled by the endless revolution into confusion of spirit with no power to listen below the noise of the mechanism" (353-354). In contrast to Alice Fletcher's firmly established persona, ${ }^{x x v}$ ensconced at "the centre of it all," Gay is "whirled... into confusion." This metaphor dimly recalls the second circle of Hell in Dante's Inferno in which lovers are caught in the whirlwind of their passions; as such it could be read as a very veiled hint of homoeroticism. ${ }^{\text {xvi }}$ At the same time, and more clearly, the comment sheds light on the heightened perceptiveness to the workings of ideology afforded by Gay's marginality as both a woman and a companion of women. Attentive to "the noise of the mechanism," she charts her trajectory on "the outer edge" through the act of writing.

19 Once she arrives in Idaho, Gay creates two fictional avatars of herself, "the Photographer" and "the Cook." These masculine and feminine personae both parody 
the gender norms associated with the frontier experience ${ }^{\text {xxvii }}$ and represent two projections of Gay's multiform identity. She speaks of these two entities in the third person, making them distinct characters in her theatre of self.

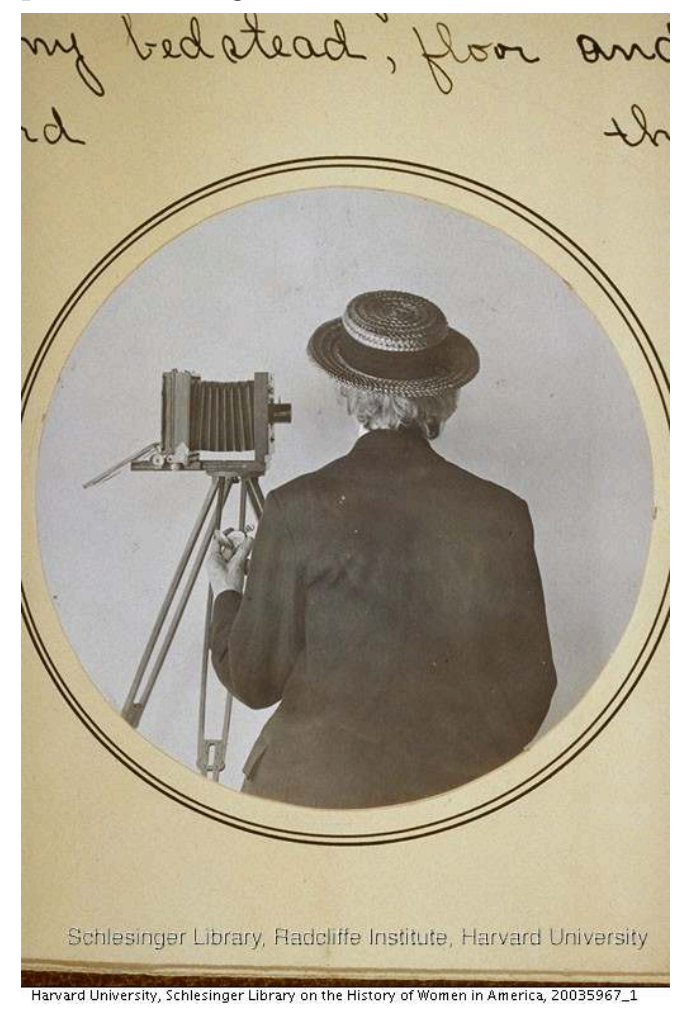

20 The Photographer appears in the very first letter, as "he" rises to the challenge of arriving at the grimy terminus of the Northern Pacific Railroad in Uniontown, Idaho: "Our Photographer, who is of Scottish descent, turns out to be the most philosophic, if not the most original, member of our party. When, in the morning sun, the bald grime of our surroundings was vividly revealed, it was the Photographer who was the least staggered of us all" (2). Why does this town so distress the feminine contingent that Gay resorts to the Photographer to analyze the situation? The women's mission is to bring civilization to the "wild" American West.xxviii Uniontown is the first glimpse of what the newly colonized space looks like. The contrast between the luxury of the train's "palace car," from whose window they admired "the majesty and beauty of uncontaminated nature" (3), and the squalor of the settlement unsettles any assurance in American progress. Thanks to the Photographer's wry commentary: the spectacle Gay depicts in Uniontown calls the imperial enterprise into question in a way that is both subversive and so subtle as to be barely detectable:"watching two pigs quarrel over the possession of a refuse heap and trying to guess the number of nationalities represented in a group of men who were also interested in the exciting spectacle,-he said that America was a country of immense possibilities and that its digestive forces were marvelous" (3).Gay's masculine persona extracts humor from contradiction. The Photographer's remark highlights the racial heterogeneity of Western immigrants and the challenge the nation faces to integrate its mixed population. Like other anecdotes in the letters to follow, it can be read as an allegory of American imperialism: newcomers to the West are like the pigs fighting for access to the garbage heap that is the visible sign of the Euro-American settlers' presence. ${ }^{x i x}$ The Photographer's pose of detachment allows Gay to enjoy the license arising from a peripheral position. In the 
persona of the Cook she implicates herself more fully in the messy business of settling the land.

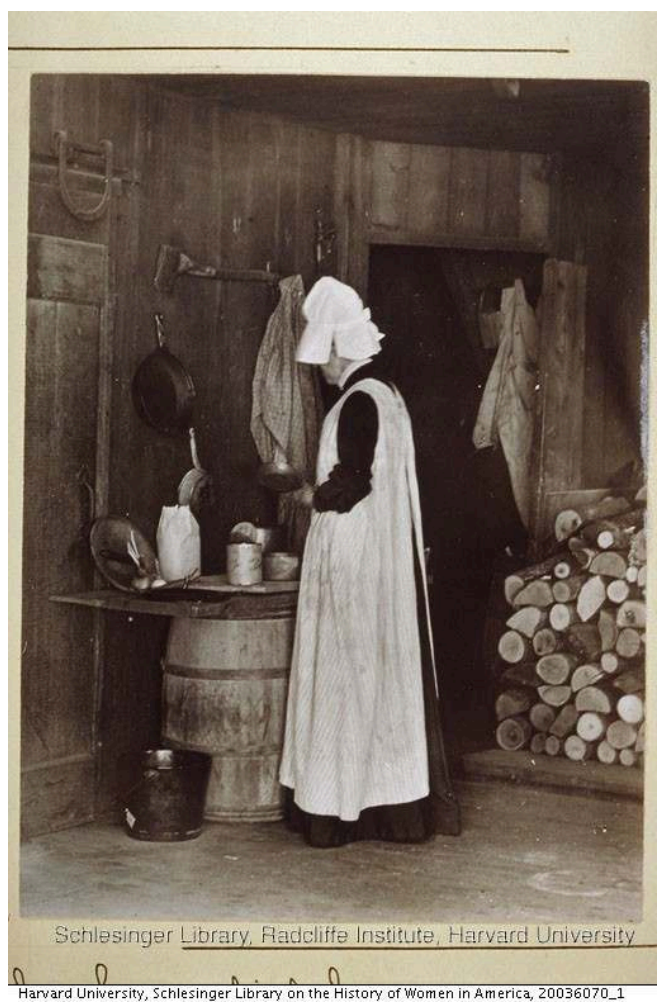

21 In her role as Cook, Gay mimics the women emigrants who transported nineteenthcentury domesticity to the Western frontier and wrote home about their trials and victories. In a photograph with the caption "Behold the Cook," she poses at the makeshift table of her rustic kitchen, busy preparing a meal from her meager supplies. Nevertheless, her humorous comment on the scene shows how her avatar deviates from the cliche of the pioneer wife: "She is devising ambrosia for the goddess, the materials for which still lie in sundry bottles and tin cans" (227). The parodic reference to the Greek food for the gods reminds us that the cook is an educated former schoolteacher and governess; at the same time, it hints at her romantic adulation of her female companion.

22 While the Photographer is credited with recording the images of the women's stay in Idaho, the Cook is represented as the literary chronicler. A metatextual passage accompanied by a self-portrait of Gay as the pen-wielding Cook describes how a spare moment favors the epistolary enterprise:

The Cook exhausts the Century and looks about for a new source of relief from the tedium of her position. She is one of those unfortunates who must always have something to do. She will write a letter! It is not often that she has the opportunity in a literary line. She borrows a sheet of paper from the Special Agent's store, leans against the pitch pine tree, places the paper on the back of a tin plate, mends her pencil with the butcher knife and writes[.] (154)

The humble props with which she stages the scene humorously undercut the pretensions to authorship that the book might suggest. 

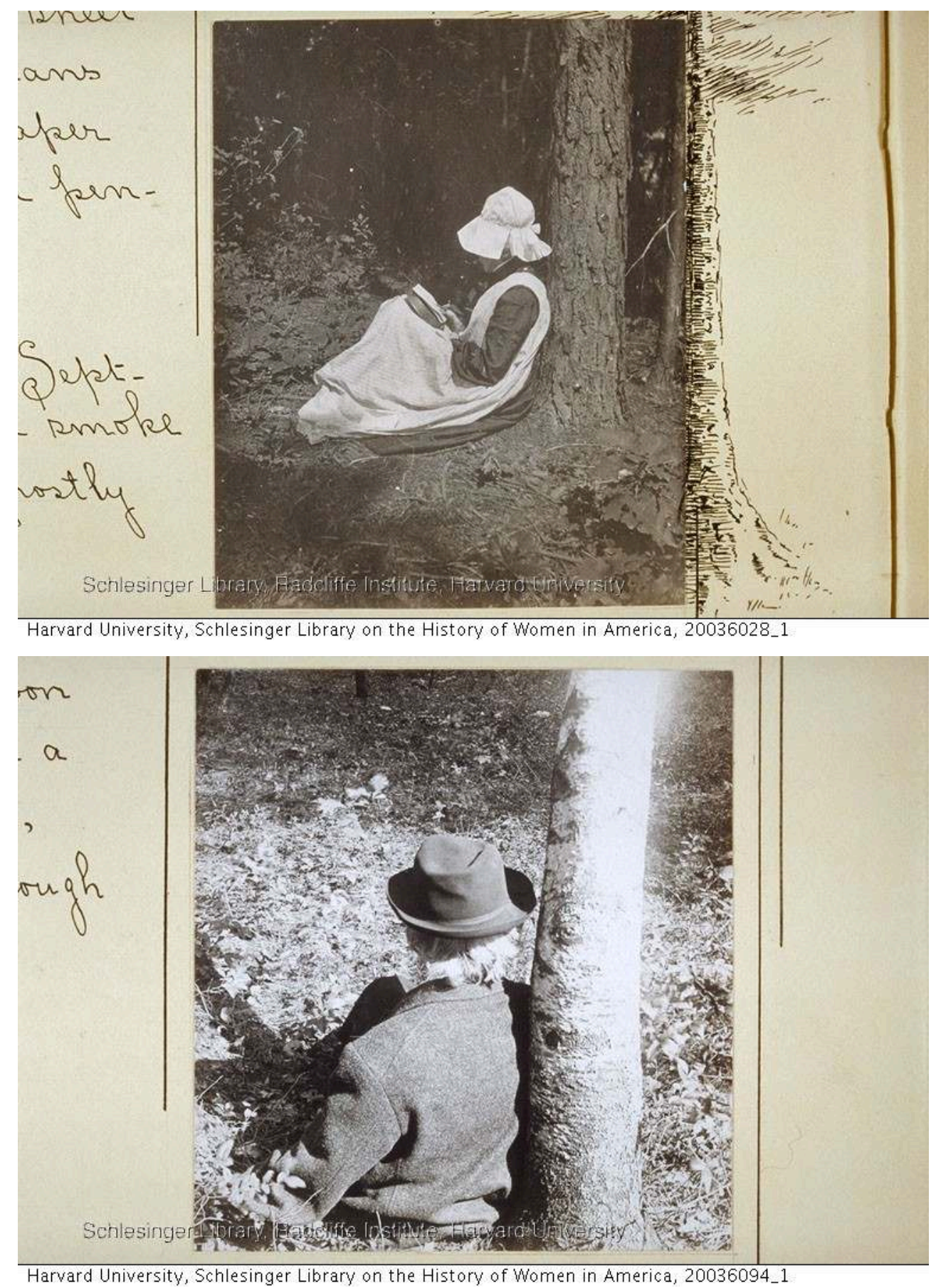

24 Gay's photograph of herself as the writing Cook both evokes and contrasts with the picture of the Photographer, illustrating both the dividedness and complementarity of her doubled self. In both images, she leans against a tree, but whereas the Cook is busy writing, the Photographer is lost in contemplation: "One might see him any day... stretched out under a tree or sitting with his weak back supported against the trunk, and his eyes closed in blissful contemplation. He had spasms of energetic purpose, but he was a genius and the Cook said she would as soon think of harnessing a hen as depending on a genius" (293). Gay's feminine avatar illustrates how "Yankee" practicality and feminine domesticity combine to meet the challenges of the West. By contrast, the philosophical Photographer has something of the Transcendentalist in his make-up. This dimension of Gay's character comes through in passages from the letters 
that enthuse on the natural setting. Nevertheless, in mentioning the Photographer's "weak back" and quoting the Cook's disparaging comment about the utility of genius, Gay makes a self-deprecating evaluation of her own artistic sensibility.

25 The hardworking, practical Cook complements the detached, skeptical "Scottish" Photographer, yet each is a caricature of a certain type. The ironic distance between the author and her avatars demands that readers refrain from assigning the sentiments they express to Gay. The Cook is the more committed advocate of Allotment, and she disparages "an Indian with hair so long and blanket so dirty" (227), but she is also the less reflective of the duo, suggesting that enthusiasm for the new policy and racial prejudice are dependent on narrowness of vision. Whether written or photographic, Gay's self-portraits always involve an element of auto-derision, yet they are also selfprotective. The masks and filters she creates allow her to position herself in relation to her ambiguous situation on the Nez Perce reservation where she is active/passive, insider/outsider, and dominant/subaltern.

26 In dividing her qualities into masculine and feminine ones, Gay mocks cultural constructions of gender. The masculine Photographer belongs to the scopic régime, capturing the world through his lens, while the feminine Cook concerns herself with the corporeal necessities. Gay uses these stereotyped figures to disturb conventional ideas of sexual difference. After all, it is the Cook who buys a gun in Chicago (Letter Seventeen), expressing the opinion that "It is shiftless to be without a gun" (291). In contrast, the Photographer's "philosophic turn of mind, speculative rather than practical" (293), inhibits him from engaging with that typically masculine accessory: "No, there was not vigor enough, even in the cook, to clean her shot gun through the medium of the Photographer" (293). In creating her two avatars Gay thus undermines the dualisms that underwrite the patriarchal and colonial structures. The Photographer/Cook duo demonstrates the limitations of genius without physicality, of mind separated from body, of "masculinity" distinguished from "femininity."

27 The photographic self-portraits of the Photographer and the Cook were made several years after the women's sojourn in Idaho when Gay and her niece collaborated in the making of her book. Jane Gay Dodge's "Brief Biography of E. Jane Gay" describes how the photographs were taken:

Years later when the two Misses Gay were selecting the letters for Miss Emma to copy, again at her home in No. Chelmsford, they improvised background and costume for pictures of the two personalities described as 'The Cook' and 'The Photographer' in the Letters. There was no reason at the time of the experiences to take such photographs, even supposing there had been any person along who could have done so. The cook's outfit of long apron and sunbonnet was exactly what Miss Gay did wear in camp. The only thing in the book which was 'faked' is her brother's coat which appears in the picture of the Photographer: no such thing in the late eighties as modern camping costume! In any case Miss Jane Gay would not have been caught dead in Mrs. Bloomer's notorious garments, for she was not of the feminist camp until after 1906, when she made friends in England with Dr. Caroline Sturge, one of the colleagues of Mrs. Despard in the British campaign for Votes for Women. (Dodge 7)

In borrowing her brother's clothes to represent the Photographer, Gay renders visible the literary cross-dressing that she performed in the letters. In spite of Jane Dodge's assurances that her aunt was committed to wearing skirts, the letters allow Gay to indulge in what Judith Butler would later term "gender trouble." A hundred years 
before Butler's revolutionary manifesto, Gay's performative theatre of self troubles binary gender divisions and heterosexual normativity. ${ }^{\mathrm{xx}}$

29 The different voices and personae that Choup-nit-ki presents paradoxically allow the writer both to enjoy an expanded form of stability and to explore alternative modes of being. Gay's book subtly mocks "Her Majesty's" rigid iconicity by setting it alongside the narrator's more flexible, ironic, and subversive personae. ${ }^{\text {xxi }}$ In her various disguises as "the unofficial member of the party," "the Photographer," and "the Cook," Gay figures her migratory subjectivity. In offering these alternatives to the name that figures on the spine of her book, she escapes the confines of unitary individuality.

30 In her self-portraits as Cook and Photographer the faces remain hidden, in part so that readers can more easily imagine their points of view and in part so that Gay remains elsewhere, even as she occupies the stage she has created. In refusing to fix a face to her dual persona, Gay turns her back on the fiction of the unitary subject. In their discussions of "faciality" in A Thousand Plateaus, Deleuze and Guattari claim that the face is a means of exerting control by fixing the body's signification, of organizing and limiting a field of possibilities (167-191). Occulting the face is a means of escaping subjectification: "when the faciality traits disappear, we can be sure that we have entered another regime, other zones infinitely muter and more imperceptible where subterranean becomings-animal occur, becomings-molecular, nocturnal deterritorializations over-spilling the limits of the signifying system" (115). Crossing ceaselessly between the faceless personae of the Cook and the Photographer as well as imagining other subject positions, Gay becomes an unidentifiable entity in motion. She eludes definition by opening a space in-between the binary gender split.

31 Her multi-media book uses art as a means of dismantling the power of the face:

But art is never an end in itself; it is only a tool for blazing life lines, in other words, all of those real becomings that are not produced only in art, and all of those active escapes that do not consist in fleeing into art, taking refuge in art, and all of those positive deterritorializations that never reterritorialize on art, but instead sweep it away with them toward the realms of the asignifying, asubjective, and faceless.

(Deleuze and Guattari 187)

Of course Gay's act of insurgency is only virtual. She makes imaginative forays from the margins to explore new territory. Although Gay's circle of acquaintances could appreciate her imaginative acts of resistance to norms, her excursions beyond the limits of gender, nationality and selfhood would probably have been imperceptible to many of the readers of The Red Man. Moreover, decades passed before the book travelled beyond the family circle. In spite of her literary ambitions, achievement remains largely personal. Moving among the manifold characters she creates in her letters, she experiences the freedom of multiple "becomings" (Deleuze and Guattari 232-309). Unlike Fletcher, who remains part of the state apparatus, Gay becomes a migratory subject whose lack of geographical and ideological stability permits her to produce a proto-"nomadic" form of writing (Deleuze and Guattari 2).

\section{The Puppeteer's Weave}

33 In its fashioning of different personae and narrative voices, Choup-nit-ki transgresses the normative grid that shapes the unitary social being. In the relations 
that she forms with her avatars and in her representations of their interactions, Gay extends herself in the manner of a puppeteer:

Puppet strings, as a rhizome or multiplicity, are tied not to the supposed will of an artist or puppeteer but to a multiplicity of nerve fibers, which form another puppet in other dimensions connected to the first: 'Call the strings or rods that move the puppet the weave. It might be objected that its multiplicity resides in the person of the actor, who projects it into the text. Granted; but the actor's nerve fibers in turn form a weave'[.] (Deleuze and Guattari 8)

If the book is a puppet theatre in which Gay assembles various actors and explores their relations with one another, readers are its audience. As such, we participate in Choupnit-ki's "rhizomatic"weave of relations. ${ }^{\text {xxxiv }}$ Insofar as we sympathize with Gay's multiform autobiographical I/she/he, we are both enmeshed in and distanced from the asymmetrical patterns of domination of nineteenth century American culture. ${ }^{\mathrm{xxx}}$

35 Gay's self-presentation allows her to transgress, without frontally challenging, the prejudices of the time that confined women to home and the rule of the husband. Choup-nit-ki stages the adventures of two lady-like New Englanders struggling to overcome the difficulties of Western life. While categories of race and class empower them, their sex makes them vulnerable. Their novel situation lets them test the limits of conventional gender roles and interrogate received ideas about femininity.

36 In one episode related in the book, Gay makes Fletcher the heroine of a struggle against a figure that she presents as symbolic of the encroaching presence of white settlers on Nez Perce land. She manages to involve her characteristically serious friend in a little light comedy by creating a series of photographs that illustrate the Allotting Agent's struggles with an insistent claimant whom she names "Box" (338-341). Gay relates how the man demands Nez Perce land on behalf of his "half breed children" and his Indian wife from a southern tribe "from down below" (338-339). Though the Nez Perce refuse to recognize the claim, and Washington orders the Agent to evict the family, Gay reports that Box remains on the land, that the litigation continues, and that "justice may be overridden and fraud prevail" (341). Tonkovich has identified this episode as a reference to a case relating to a claim by Mrs. Julia Cox, "a native woman who had been one of two wives of William Taylor Cox" (Allotment 264), a dispute "so central... in the last years of allotment that the usually dour Fletcher collaborated with Jane Gay and posed for a series of four ironic photographic images (clearly made years after the fact) that in their conception, resemble a Thomas Nast political cartoon" (263). Though the native woman sued for the land, Fletcher obviously interpreted her claim as her white husband's illegitimate bid to benefit from allotment. This enabled her to view her own opposition to the claim as a defense of Indian rights against rapacious settlers, rather than as the dispossession of an indigenous woman.

37 Letter Twenty Two stages Her Majesty in a running fight against a cardboard effigy that puns on the name Box, figuring Fletcher's tribulations as a combat against white male dominance (340-341). Fletcher crushes the belligerent puppet only to have it rise up combatively to be defeated once more. Still, her triumphant victory is assured by the effigy's flimsy composition. The normally diminutive Fletcher towers over the cardboard man, and in the final image her efforts to "REGISTER TRIBE" reduce the "BOX CASE" to a disorderly pile of trash. 

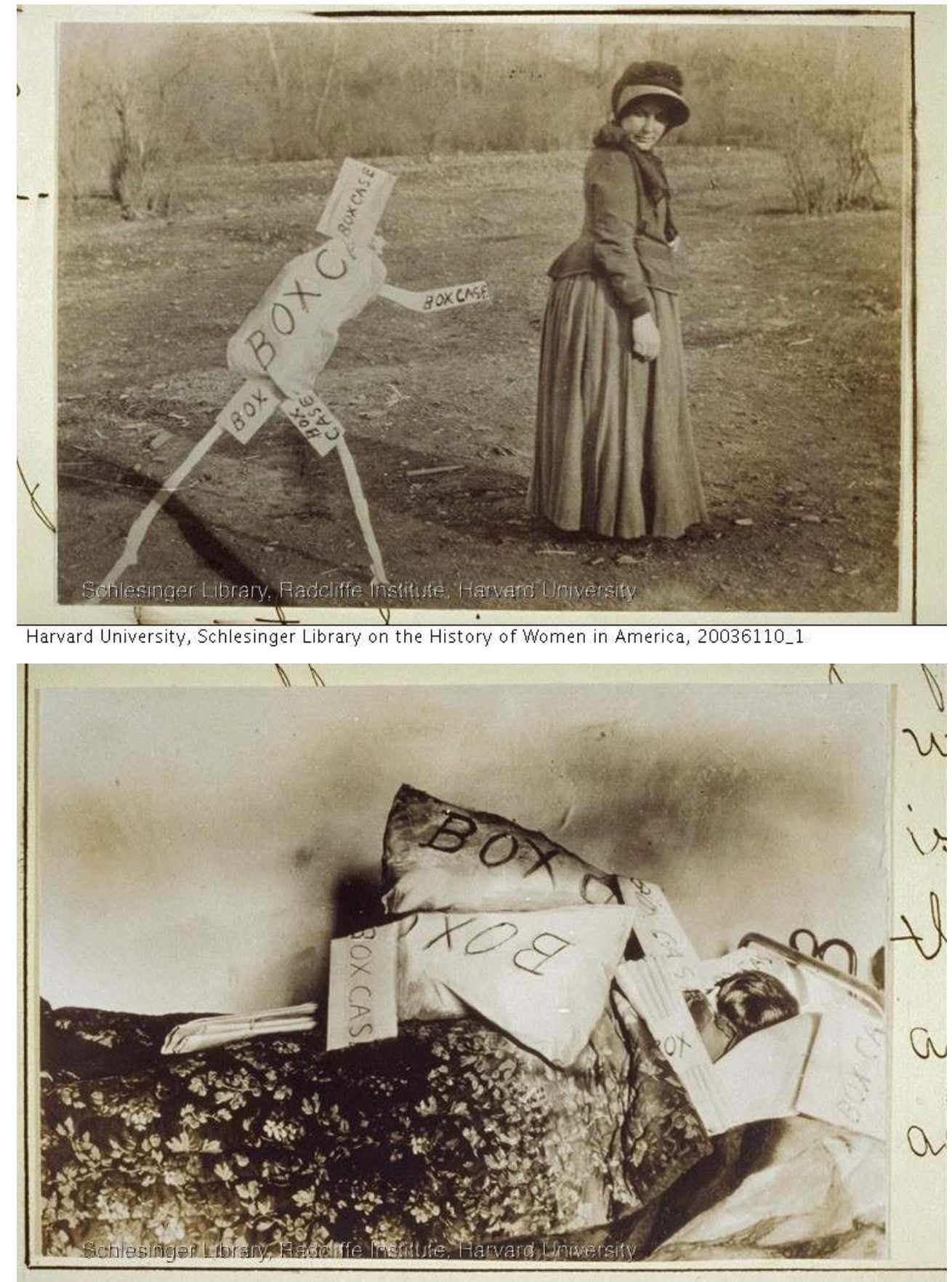

Harvard University, Schlesinger Library on the History of Women in America, 20036111_1 

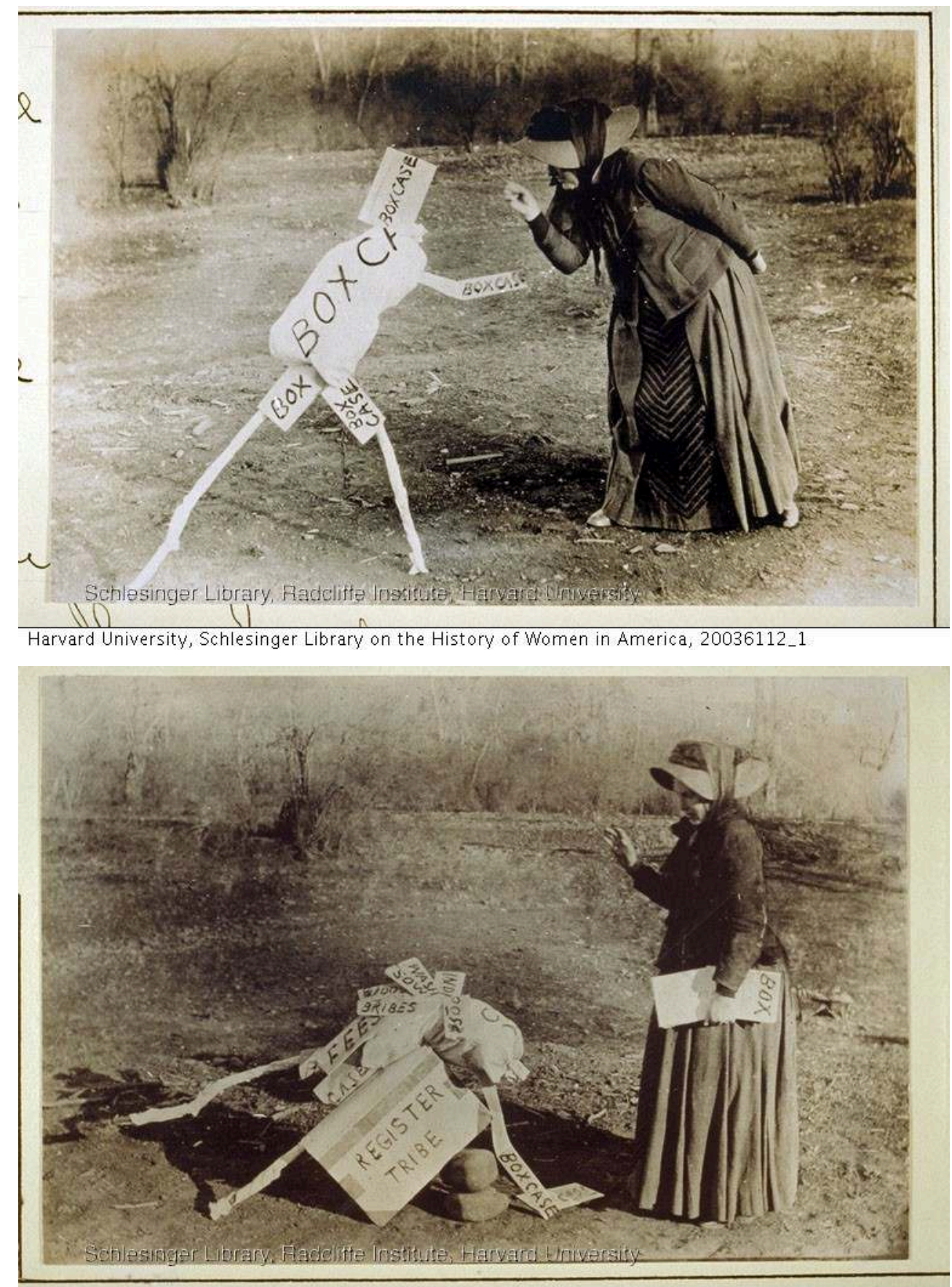

Harvard University, Schlesinger Library on the History of Women in America, 20036113_1

38 In renaming Cox as Box, Gay is probably alluding to the popular nineteenth century comic operetta, Cox and Box or the Long Lost Brothers in which two men, James John Cox and John James Box, the former who works by day and the latter, by night, unknowingly share the same room rented by an unscrupulous landlord. xxxvi The plot's similarity to the Cox case, where two claimants disputed the same allotment, ${ }^{\text {,xxvii }}$ must have appealed to Gay's sense of humor. Her caricatural mise en scene simplifies and distorts the legal wrangle in order to refute suspicions that Allotment would benefit the land-hungry newcomers who felt that their hegemonic status gave them title to the land. If, as Tonkovich suggests, the photographs were made years after the women's stay in Idaho, they might have offered Fletcher a measure of consolation for the mitigated success of her mission. 
39 Gay's puppet-theatre creates a space of play in which contradictions become a source of humor. In many instances the conventions of game mitigate potentially subversive passages. In one letter Gay represents the Cook and the Photographer acting as would-be anthropologists, imitating Alice Fletcher's investigations with comic ineptitude. They try to make anthropometric measurements of the Nez Perce with calipers made from the Photographer's chair (369), and they dig for artifacts with an old fire shovel and an iron spoon in a supposed burial site that turns out to be a "cooking range" (374). This burlesque episode has a satiric edge, nonetheless, for the brief bout of "anthropometric mania" (368) fails to solve the "puzzle" of why Nez Perce heads are unexpectedly large (370). The satire turns against the Indians, whom the Cook credits with an unusual "thickness of skull" (375), but it does not spare the nascent science of anthropology, that draws conclusions before looking for evidence to corroborate them.

40 As the puppeteer of her self-created Western theatre, Gay orchestrates a challenge to the prevailing doxa. At the same time, as she extends herself through the puppeteer's weave, she avoids being held accountable for the positions that she stages. Responsibility for perceiving the contradictions and coincidences that the letters reveal devolves upon readers.

\section{Exposing Limits}

41 Inevitably, in playing at crossing boundaries Gay confronts situations that expose the restrictions that curtail both her own liberty and that of the Nez Perce. While her book celebrates the personal expansion that she experiences in going west, it also reveals a darker reverse side of the picture. The liberty she enjoys as a member of the dominant race contrasts with the restrictions placed on Nez Perce autonomy under the Allotment Act. Moreover, Gay finds that her own freedom is curtailed by her gender. Though the civilization she represents affirms independence and self-determination as central values, they only apply when exercised by white males. The United States Constitution does not guarantee freedom for all, and, indeed, the rights and privileges enjoyed by some depend on the state's power to impose constraints on others.

42 Some of the restrictions Choup-nit-ki reveals depend on gender divisions. The two friends enter territory that requires qualities their culture designates as masculine. With the help of the Nez Perce, they negotiate the rugged terrain of the reservation, but there are moments when they must fall back on their own resources. Their resulting performance leads to an interrogation of the restraints shaping Euroamerican femininity. At one point, after a struggle to erect a barrier to guard a precious water hole from wild horses, Her Majesty and the Cook reflect on the question of women's emancipation. While the former claims that inequality as "largely a matter of clothes," the latter adds that there is also the question of "muscular strength" (320), acknowledging the physical effort required to perform a masculine role. The writer goes on to relate the men's return to camp: "the surveying party, with masculine unconcern, pulled down the painfully erected fence and let their horses absorb the last drop of the priceless fluid and then rode away, leaving the rails tramped into the black bog" (320). The description of this outcome lends an allegorical dimension to the episode. It illustrates the men's unheeding exercise of their gender prerogatives-they are free to ride away, while the two women, hampered by their clothing and lack of 
muscular strength, are confined to the camp. Moreover, the episode serves as an example of the rapaciousness of the imperial enterprise; having consumed the last of a precious resource, the men freely abandon the ravaged remains.

43 Ironically, Gay observes that the limitations imposed on female citizens of the United States, even in the far reaches of the West, contrast with the freedoms enjoyed by their Nez Perce counterparts:

The men can jump on their ponies and ride off to see a man whenever the social instinct prompts.... But diversions are not for the frontier woman unless she is an Indian woman. She can jump on her pony and ride away whenever she chooses. The children are no hindrance. She can hang them up in a tree, to wait her return, or she will tie her cradle-board to her saddle and gallop off as free as her husband; freer, indeed, for she owns her children, her horses, her home and all its belongings. (65; original underlining)

Gay's underlining in this passage emphasizes the magnitude of the rights and liberties that she sees Indian women enjoying in contrast to the white women settlers vying for the same space and supposedly representing a model to which to aspire. The photograph accompanying this reflection, provocatively entitled "Owner of the Lodge," illustrates a matriarchal family in which three generations of women enjoy their possessions along with the freedoms they imply. Even the little girl holds the reins of the pony that would offer her a route to escape patriarchal domination within the tribe.

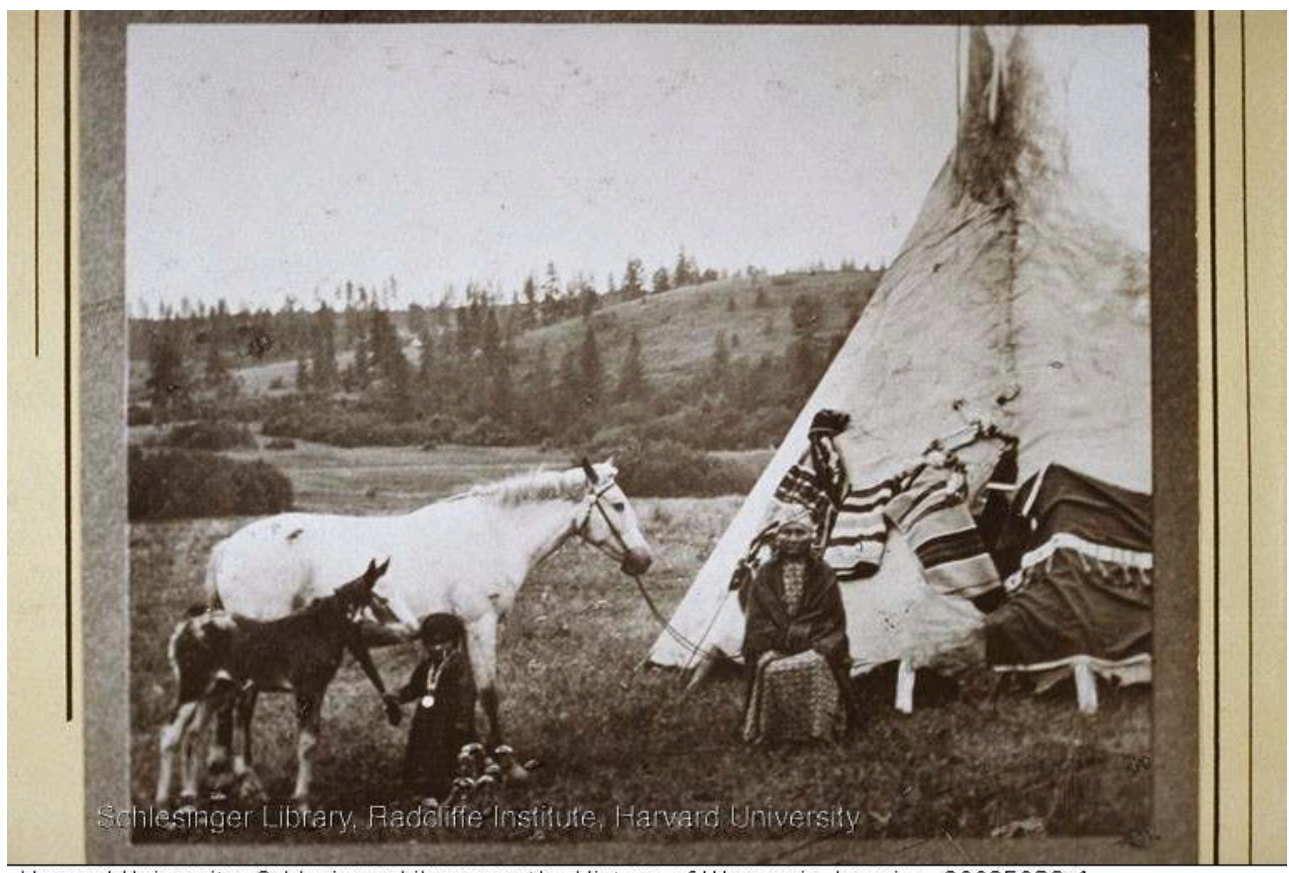

Harvard University, Schlesinger Library on the History of Women in America, 20035986_1

45 In a concluding comment to the female addressee of this letter, Gay tries to place the subaltern position of Euro-American woman in a positive light: "You see, dear E., that civilization has been built up largely upon the altruism of the woman, at the cost of her independence; and is still an expensive luxury to her" (35). The temporal adverb in the final comment-"civilization... is still an expensive luxury" (my emphasis) expresses her indignation and her hope for change. Moreover, Gay implies that civilization is a frivolous "luxury" compared to the more basic necessity of independence. An example of the dialogic nature of the book, this passage echoes the 
speech Alice Fletcher made at the first conference of the International Council of Women in 1888, where she informed listeners that an Indian woman was "free to choose her husband if she so desires" and "independent in the use of her possessions." By contrast, the Euro-American woman "has given [much] of her own freedom to make strong the foundations of the family and to preserve the accumulations and descent of property" (Fletcher quoted in Janiewski 173). Readers are left to consider the irony of these two unmarried women working to introduce to the Nez Perce reservation gendered stereotypes that they themselves are beginning to question in both words and acts.

46 The Dawes Act promised to make American Indians into citizens of the nation, but, as the two women recognize, that new privilege is heavily biased in favor of men. Gay invokes the Nez Perce example to imagine a better life for American women that would join civilization with freedom, mobility, independence, and equality. Indeed, Fletcher concluded her speech to the International Council of Women with the hope that women would be able to change "the laws of the land [so that] they shall know neither male nor female, but grant to all equal rights and equal justice" (Fletcher quoted in Janiewski 173).

47 Still, while the two women dreamed of freedom and justice, the Allotment policy worked to constrain the movements of the Nez Perce, to confiscate their land, and to trap them in an alien way of life. In Choup-nit-ki, Gay appears more lucid than her friend about the flaws in the system she is helping to implement, although there is much that she does not express directly. ${ }^{\text {xxix }}$ The shifting of pronouns and the splitting of personae in the letters permit expressions of ambivalence without implicating anyone directly in the critique of the Allotment policy. While the writer's various disguises facilitate selfexamination and self-criticism, they also protect her by masking the source of any particular expression.

48 Gay invites readers to see that from the Nez Perce point of view the scheme being proposed "looks queer" (38). However, she seems divided between empathy and impatience with the Indians' resistance to allotment, and she stages her ambivalence in the contrasting responses of the Cook and the Photographer: "while the Cook lays violent hands upon her inclination to resist the patient endurance of inaction... the Photographer gracefully accepts his laissez-faire role" (40). Gay thus claims an inbetween position that relativizes and humanizes the conflicts taking place on the Nez Perce reservation. If the letters advance arguments in favor of dividing the reservation into individual allotments, they also expose the violence involved in ending tribal culture.

49 While the writer's expressed position remains ambivalent, her irony and humor suggest alternative perspectives to the official orthodoxy. Describing the celebration of Decoration Day on the reservation, ${ }^{\mathrm{xl}}$ she states laconically, "We happened to see the procession of school children going out to decorate the graves of the soldiers who slew their fathers in the Joseph war" (235). The violence implied in the verb "to slay" recalls the imbalance of the forces opposed during the U.S. Army's pursuit of Chief Joseph and his people. The Nez Perce leader and his band resisted the relocation from their homeland in the Wallowa Valley to the reservation in Lapwai, Idaho and they were pursued across the western territories in a campaign known as the Nez Perce War. If the word "happened" suggests the writer's casual witnessing of the event, the two photographs showing the line of boys and the line of girls bearing flowers to their 
former enemies' graves give it more importance. Uniformed and placed in orderly ranks, the children bow their heads before the graves. Viewers must decide whether their pose shows the children's respect for the soldiers and pride in their own identical uniforms or their resignation to their subaltern position as the losers in the conquest of the West.
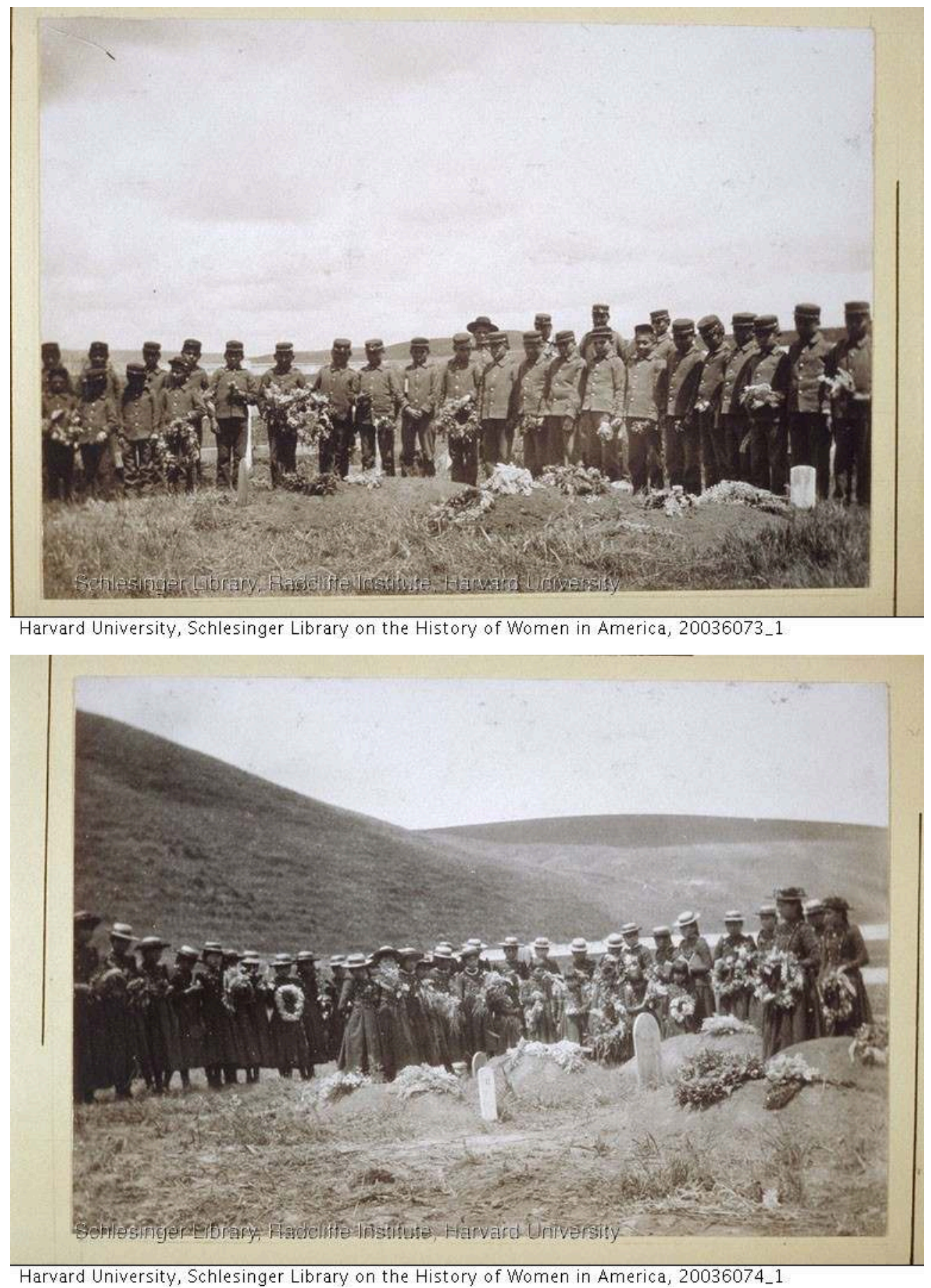

50 Elsewhere, the continuing violence perpetrated by the United States' Indian policy is suggested through metaphors that liken the women's mission to an armed conflict: "We are still skirmishing on the outposts of our undertaking, still fighting preliminary battles and working on the collateral lines of our special object" (121). Though these comments could be dismissed as conventional rhetoric, Gay's implicit critique of the imperialist design underpinning the Dawes Act becomes more difficult to miss in the 
lines that follow, describing how "Her Majesty sits all day long in her inquisitorial chair" while "sections are drawn and quartered and driven like wedges into the Indian brain by the Interpreter" (122). In comparing her friend to an Inquisitor, the Presbyterian Gay reveals a profound uneasiness with her mission in Idaho. The state apparatus Fletcher wields assaults the land, which is "drawn and quartered" and then, in turn, assails the Indians, as the sections become "wedges" that penetrate the Indians' minds, dividing them from each other and alienating them from their culture and from themselves.

51 In a metaphorical thread running through the letters, Gay describes the obstacles in the way of Fletcher's aim "to catch her Indian" (99). The image of capture connects Fletcher's work with the earlier U.S. Army campaigns to track down and imprison the last of the Indians resisting confinement on the reservations. Indeed, such militarystyle rhetoric appears with some frequency in Assimilationist discourse. An article by Frances E. Willard, published in The Red Man two months before Gay's first letter appeared there, describes a visit to the Carlisle Indian Industrial School. Commending Captain Pratt's work at the school, Willard admires the disciplined students moving in orderly ranks, and muses: "Better to capture them by love, uniform them in blue, and kill them with kindness than to send out our own boys in blue to be killed by them" (7). Pratt himself famously spoke of "kill[ing] the Indian... and sav[ing] the man" (Churchill 14). Education was to be the means of subjugating the Indians. It was not really a coincidence that the Carlisle Indian School "had been a military station since 1857; in later years it had been used as a recruiting office and cavalry drill ground for prospective Indian fighters" (Willard 6). Indian education advocate Merril E. Gates spoke proudly of conquering the Indians with the help of "a standing army of schoolteachers" (Adams 27). Despite the benevolent intentions of the reformers who argued that their attitude to Indians was more humane than war, the psychic and physical damage the boarding schools inflicted upon their pupils now makes the Assimilationists' words sound bitterly ironic.

52 In her own use of the capture trope, Gay seems more alert to its somber implications. She follows it with a seemingly trivial anecdote that becomes a parable illustrating the unhappy consequences of the government's Indian policy. Discovering a family of mice nesting on the pantry shelves in Kamiah, the Cook places them in a cotton-lined box and removes them to the shed. Later she discovers that the mouse and its young have returned to the shelves and met a sad end at the bottom of a pitcher. Her account of the way the Surveyor and the Cook respond lends an allegorical dimension to this household accident: “'That's what you get', said Briggs, 'for trying the Indian policy on a new species.' The Cook decently interred the family, feeling all the time as if she were a murderer. The belligerent attitude of that mouse reminded us all of a sadder story and in the ill-regulated mind of the Cook, to this day, that mouse 'removal' is mixed up with the story of Chief Joseph" (100). The Cook clearly sympathizes with Chief Joseph's refusal to accept the confiscation of his homeland, and her responsibility for the mouse family's deaths mixes with guilt for her nation's treatment of the Indians. At the same time, as the Surveyor suggests, the Cook's meddling with the mouse family parallels the women's involvement in allotment; the displacement and deaths of the mouse family are the result of her efforts to bring an exemplary American cleanliness to the Idaho campsite. The mouse episode illustrates the writer's ability to suggest surprising rhizomatic connections among elements that would normatively be kept distinct. It could be read as Gay's tacit act of contrition and 
her acknowledgment of responsibility for the upheaval caused by Fletcher's work as Allotting Agent. xli $^{2}$

53 In Choup-nit-ki the writer's expressions of satisfaction with the steps the Nez Perce are making toward assimilation war with the sympathy for "the unsubjugated Indian" she discovers when Chief Joseph pays a visit to Alice Fletcher at Lapwai:

He cannot be persuaded to take his land upon the Reservation. He will have none but the Wallowa valley, from which he was driven; he will remain landless and homeless if he cannot have his own again. It was good to see an unsubjugated Indian. One could not help respecting the man who still stood firmly for his rights, after having fought and suffered and been defeated for their maintenance. (236) "firmly."

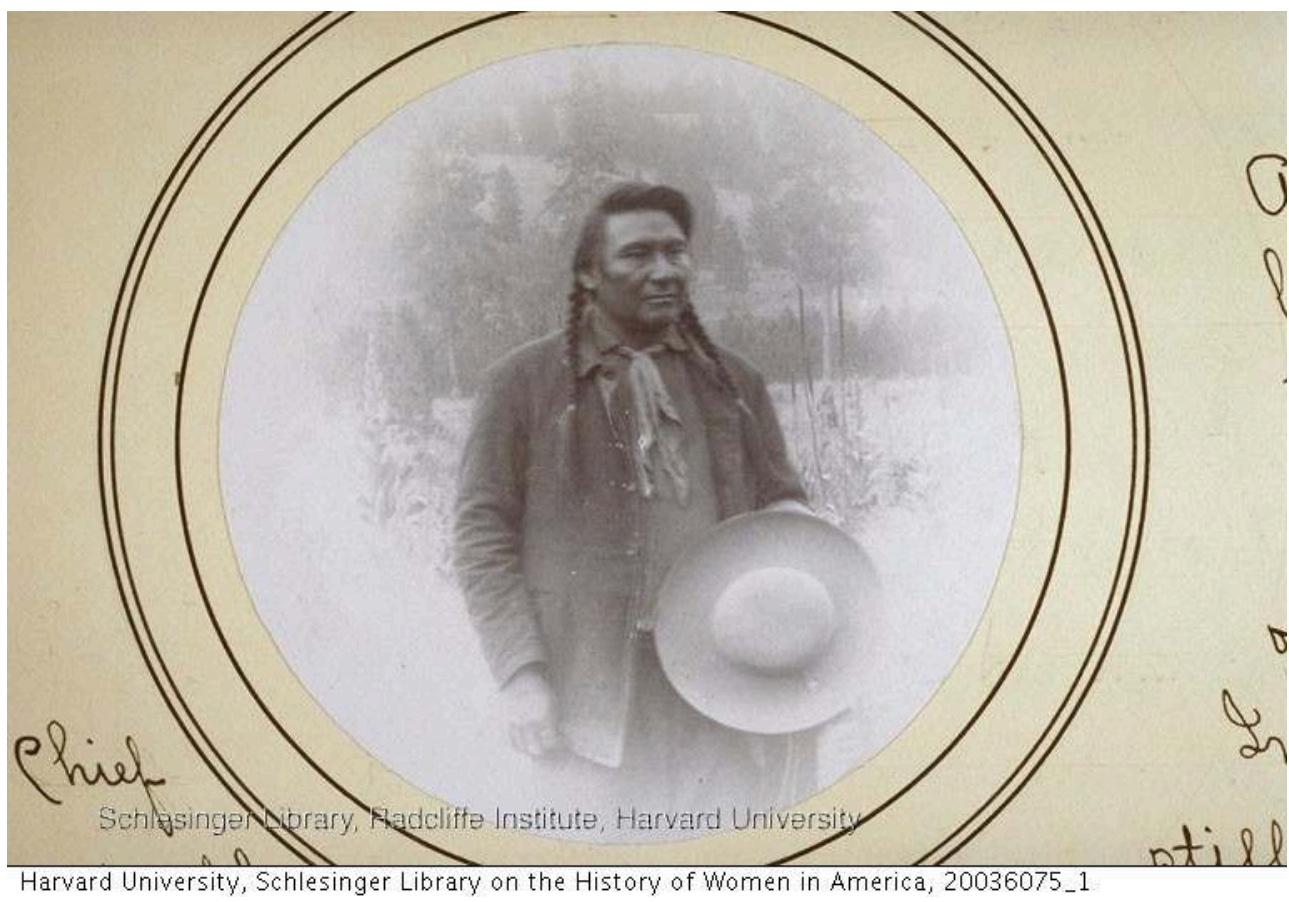

The image comes from a larger photograph that poses the Chief at the center of the frame, with his face fully revealed to both Alice Fletcher and the camera. Gay's respect for Chief Joseph is evident both in the importance given him in the photograph and in the terms with which she characterizes his resistance ("good"; "stood firmly") and his dispossession by the U.S. Army ("he was driven"; "his own"; "his rights"). 


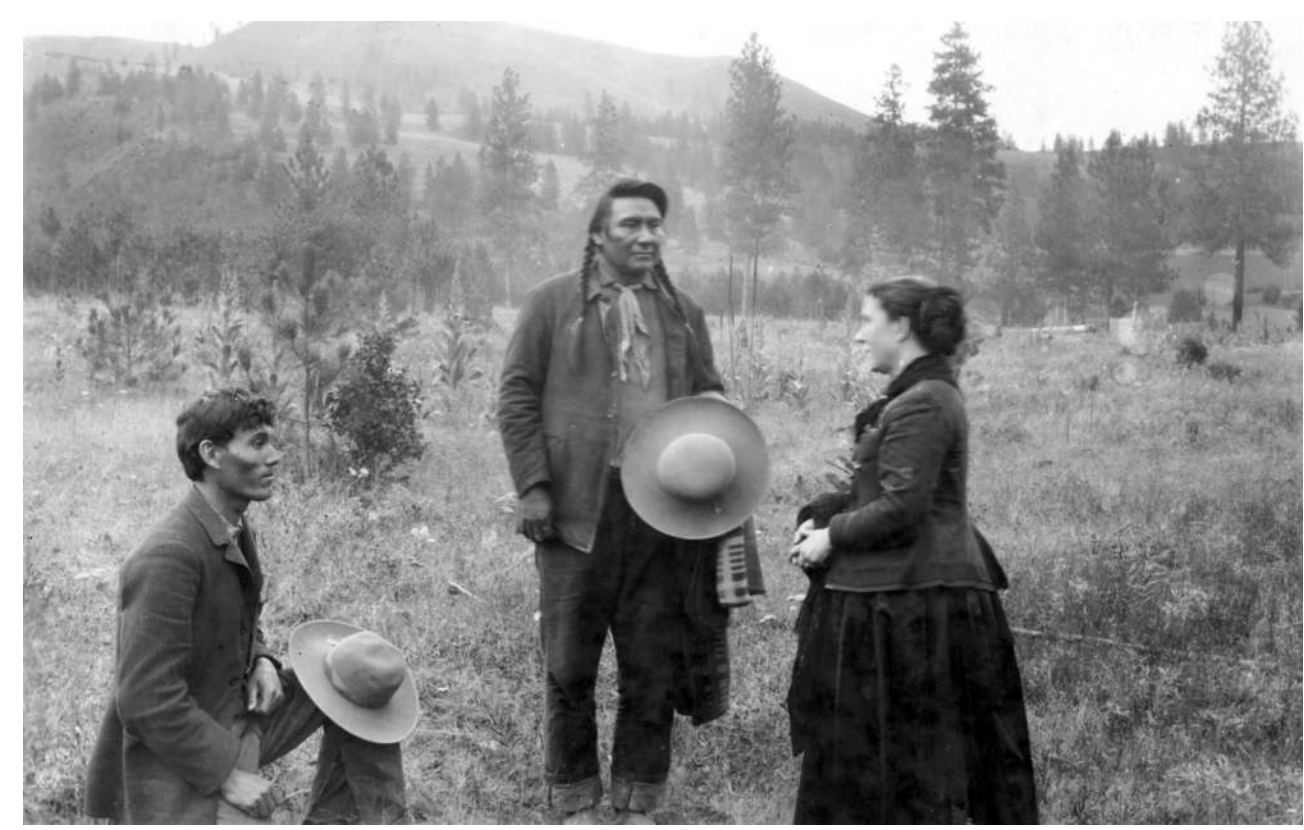

56 In the photograph commemorating their meeting, xlii Fletcher appears in profile on the right, her face turned toward Joseph. James Stuart, Fletcher's Nez Perce assistant, xliii kneels while looking bizarrely into space, engaging with neither of the other two. Although Alice Fletcher explained in a letter that Stuart adopts this apparently subaltern position simply "to break the line of 3 standing" (Fletcher qtd. in Tonkovich, Allotment 2), he clearly contrasts with the recalcitrant defender of earlier treaty rights.The staunchest Nez Perce ally of the Allotment project, Stuart appears defeated and compliant in the photograph. Tonkovich argues that his kneeling pose "suggests his respect for this legendary hero" ("Lost" 38) and indeed this may be the case. One of the letters in Choup-nit-ki simply remarks Stuart's "peculiar habit of going down on one knee and putting his hat on the other when under any stress of emotion" (45). Although it is impossible to recapture the state of mind of any of the three figures in the photograph, Gay's verbal and photographic response to the event suggests the participants' ambivalent entanglement.

57 To convey the complexity of her encounter with the Nez Perce and U.S. Indian policy during the four summers she spent in Idaho, Gay chooses to fashion a heterogeneous composite of voices, personae and images. Her book renders a subject in process, in the throes of political and personal transformation. While she collaborated in forcing change on the Nez Perce, the experience seems also to have altered her, calling into question previously held certainties and demanding a creative response to the resulting confusion.

\section{5. "Retrospection"}

58 Pieced together retrospectively from selected extracts from Gay's correspondence and from photographs taken on-site or staged subsequently back in the East, Choup-nitki both documents and fictionalizes Gay's sojourn with the Nez Perce. In contrast to a number of contemporary texts written by women about the settling of the West, ${ }^{\text {xliv }}$ Gay has no praise for the courage of white settlers or for their triumph over Indian savagery. On the contrary, since she was not in Idaho to stay, she could condemn the 
lawless behavior of the settlers. As opposed to ego-centered memoirs of nineteenth century men chronicling their discovery of the West, ${ }^{\text {,lv }}$ her book describes a decentered subject's interaction with an unfamiliar people and territory. At the same time, it mocks pretentions to objective judgment and intimates that knowledge is situated (Haraway 183-201), for one's perception of the world is inflected by historical placement. It presents a multimedia composition instead of a strictly narrative approach, an open polyvocal relation instead of a teleological narrative. Visually and discursively, the book offers relativistic multi-angled impressions rather than focused ideological orientations.

59 Choup-nit-ki abandons the rhetorical principles that produce coherence, thereby breaking with the conventions that produce the illusion of a stable, unitary subject and that found both autobiographical writing (Smith and Watson 27) and the legal and

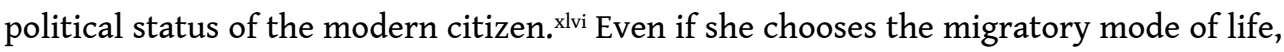
going "principally from one point to another," her book opens up a smooth nomadic space "between two points... the in-between... the intermezzo" (Deleuze and Guattari 380). The decentered, diffracted self-expression of its migratory protagonist prefigures new forms of self-expression for modernity. At the same time, as Tonkovich has shown, Gay's photographs attest that the Nez Perce were also in motion, finding creative responses, "resistant countermovement[s]" to "colonial incursions such as allotment" ("Parallax" 69).

60 The narrating voice of Choup-nit-ki foregoes the authoritative positions of the detached reporter or the militant witness. The writer's disseminated personality offers a diffracted vision of events, granting limited access to all participants. What makes the book so intriguing and original is the fact that subject and object are not clearly demarcated-this conventional duality is strangely blurred as evinced in the portraits of the Photographer presenting his/her back to the camera, the Cook engrossed in the act of writing, or the figure in the photograph on the book's final page who gazes out onto a body of water, potentially a reflecting mirror, but one that gives back no face that would identify a subject. What one sees with these faceless figures is a cross between a vision and an absence of view, an unidentifiable observer evoking the perspective of an unspecified witness embedded in an indeterminate setting. 


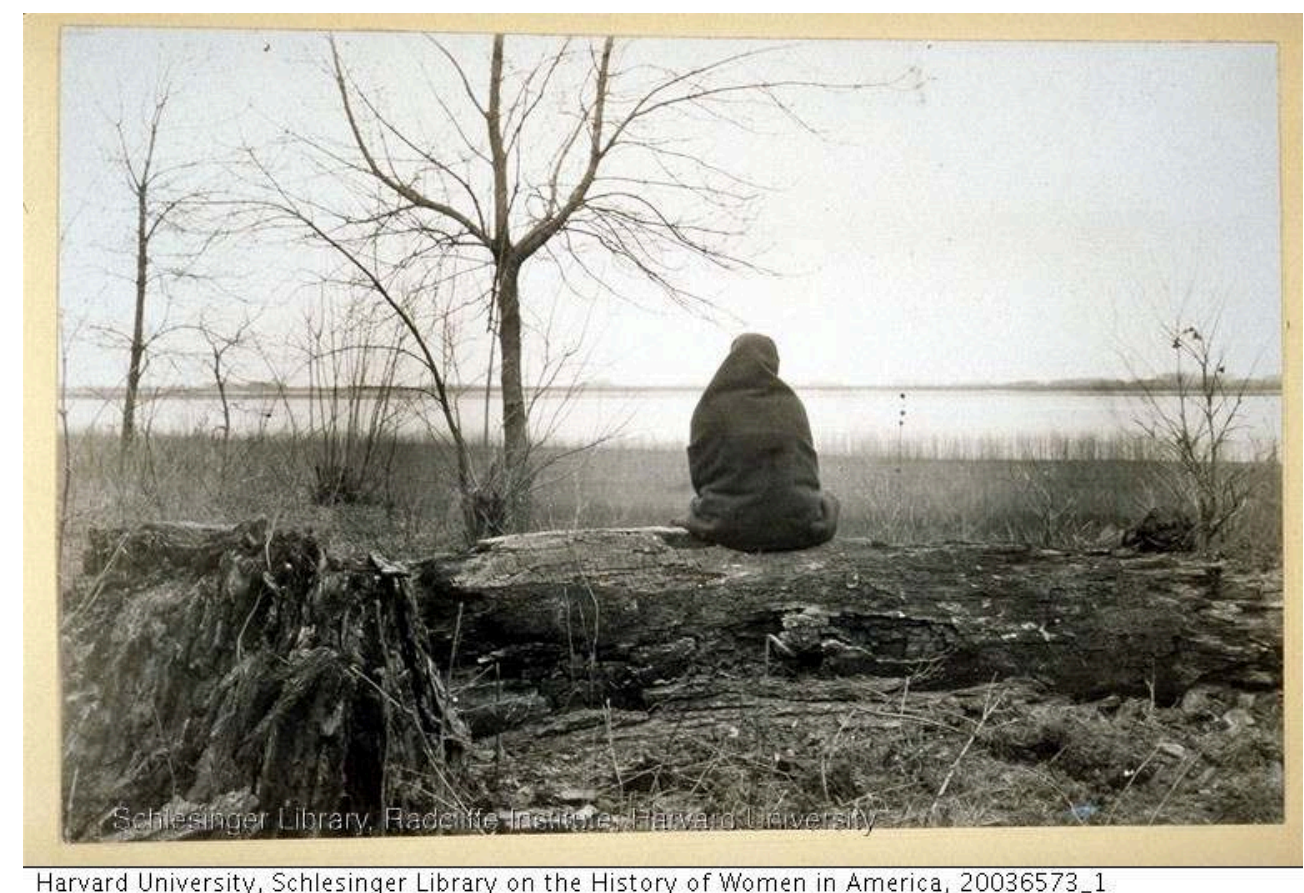

61 Intriguingly, the woman in the book's final photograph, "Retrospect," could be either a Euro-American wrapped in a shawl or an American Indian in a traditional blanket. The image blurs the culturally constructed boundaries between races and genders. As the final image in a book that is partly about place, its location is difficult to pinpoint. The photograph was probably not taken in Idaho. In fact the setting resembles another of the photographs appearing in Choup-nit-ki, entitled "Omaha Madonna" (219) and illustrating the stop the two women made in Nebraska to visit the Omaha and Winnebago in May 1890.

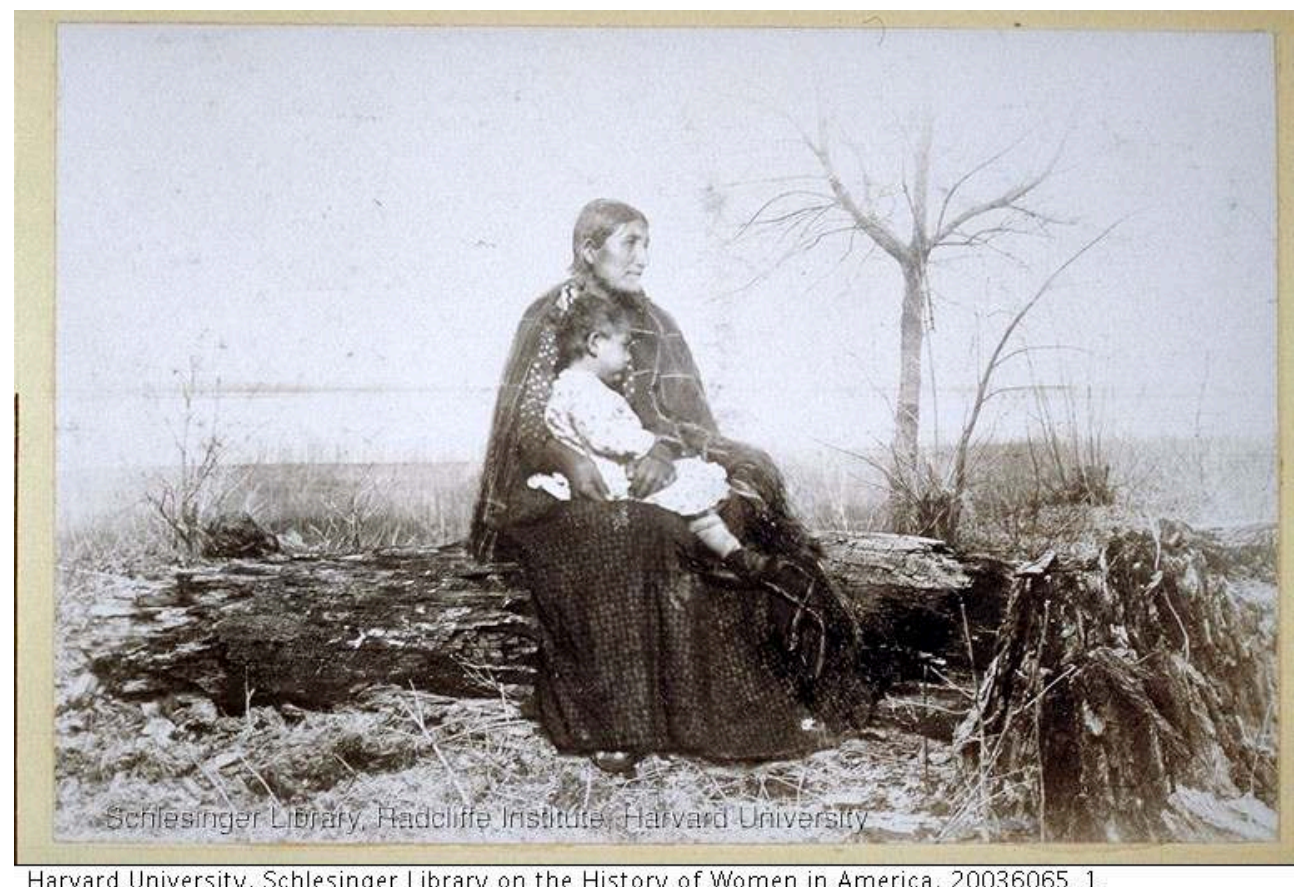

62 Seated in a wintry landscape among leafless trees, the muffled figure in "Retrospect" could be engaged in a meditative consideration of the past, perhaps even 
a Proustian quest to recover lost time. Indeed, the pose suggests introspection as well as retrospection. Nevertheless, unlike Proust's narrator, Gay presents a faceless viewer contemplating an unspecified landscape that opens onto infinity. With this final image, the book turns away from allotment to picture a space where laws and structures do not hold, evoking perhaps the smooth space in which Deleuze and Guattari's nomads circulate. The unseen gaze of the anonymous figure indicates the uncharted directions that readers might follow, the lines of flight that might lead them beyond the striated lines traced by the authorities.

63 Ultimately, the book's multiple filters and masks make it impossible for us to know E. Jane Gay. The protean persona remains an enigma as Gay creates a montage of "states of being" that combine subjectivity and objectivity, proximity and distance. These interlocking "states of being" are not traditional characters interacting with each other but various impersonations that project Gay's divided and conflicted appropriations of the scene. The most intriguing passages in the letters present a form of self-conscious schizophrenia (in the positive Deleuzian sense of the word) that apparently abides by the social constraints of the times yet projects itself far beyond them. The great accomplishment of Choup-nit-ki is its creation of a multiple transgender composite that both exemplifies and exposes the imperialistic ideology that was attempting to shape the West to its own ends.

\section{BIBLIOGRAPHY}

Adams, David Wallace. Education for Extinction: American Indians and the Boarding School Experience, 1875-1928. Lawrence: University Press of Kansas, 1995. Print.

Bakhtin, Mikhail M. The Dialogic Imagination: Four Essays. Trans. Michael Holquist. Austin: U of Texas, 1981. Print.

Baym, Nina. Women Writers of the American West, 1833-1927. Urbana: University of Illinois Press, 2011. Print.

Braidotti, Rosi. Nomadic Subjects Embodiment and Sexual Difference in Contemporary Feminist Theory. New York: Columbia UP, 1994. Print.

Butler, Judith. Gender Trouble: Feminism and the Subversion of Identity. New York: Routledge, 1990. Print.

Cahill, Cathleen. Federal Fathers and Mothers: A Social History of the United States Indian Service, 1869-1933. Chapel Hill: University of North Carolina Press, 2011. Print.

Churchill, Ward. Kill the Indian, Save the Man: The Genocidal Impact of American Indian Residential Schools. San Francisco: City Lights Books, 2004. Print.

Deleuze, Gilles, and Félix Guattari. A Thousand Plateaus: Capitalism and Schizophrenia. Trans. Brian Massumi. Minneapolis: U of Minnesota, 1987. Print.

Deleuze, Gilles, and Claire Parnet. Dialogues II. Trans. Hugh Tomlinson and Barbara Habberjam. New York: Columbia UP, 2002. Print. 
Deloria, Philip J. Playing Indian. New Haven: Yale UP, 1998. Print.

Dodge, Jane Gay. "Brief Biography of E. Jane Gay." Published online in the Jane Gay Dodge Papers, 1861-1951. A-20. Schlesinger Library on the History of Women in America, Radcliffe Institute, Harvard University, Cambridge, Mass.

Gay, E. Jane. Choup-nit-ki: With the Nez Percés. London: The Bindery, 1909. Published online with the Jane Gay Dodge Papers, 1861-1951. A-20. Schlesinger Library on the History of Women in America, Radcliffe Institute, Harvard University, Cambridge, Mass.

---. With the Nez Perces: Alice Fletcher in the Field, 1889-92. Eds. Frederick E. Hoxie, and Joan T. Mark. Lincoln: U of Nebraska, 1981. Print.

Genette, Gérard. Paratexts: Thresholds of Interpretation. Trans. Jane E. Lewin. Cambridge, England: University of Cambridge Press, 1997. Print.

Georgi-Findlay, Brigitte. The Frontiers of Women's Writing: Women's Narratives and the Rhetoric of Westward Expansion. Tucson: U of Arizona, 1996. Print.

Greenwald, Emily. Reconfiguring the Reservation: The Nez Perces, Jicarilla Apaches, and the Dawes Act. Albuquerque: U of New Mexico P, 2002. Print.

Haraway, Donna. Simians, Cyborgs and Women. New York: Routledge, 1991. Print.

Hischak, Thomas S. Broadway Plays and Musicals: Descriptions and Essential Facts of More than 14,000 Shows through 2007. Jefferson, NC: McFarland, 2009. Print.

Jakobson, Roman. "Shifters, verbal categories, and the Russian verb." Word and Language. Selected Writings. Vol. II The Hague: Mouton, 1971. 130-147. Print.

Janiewski, Dolores. "Learning to Live 'Just Like White Folks': Gender, Ethnicity, and the State in the Inland Northwest." Gendered Domains: Rethinking Public and Private in Women's History. Ed. Dorothy O. Helly and Susan M. Reverby. Ithaca: Cornell UP, 1992. 167-180. Print.

Kaplan, Amy. The Anarchy of Empire in the Making of U.S. Culture. Cambridge, Mass: Harvard UP, 2002. Print.

Lejeune, Philippe. Le Pacte Autobiographique. Paris: Seuil, 1975. Print.

McBeth, Kate C. Letter to E. Jane Gay, 10 November 1902. MS. 4558, Papers of Alice Cunningham Fletcher (1838-1923) and Francis La Flesche (1859-1923). National Anthropological Archives. Transcribed by Nicole Tonkovich, 15 Jan. 2007.

Mark, Joan. A Stranger in Her Native Land: Alice Fletcher and the American Indians. Lincoln, Nebraska: U of Nebraska P, 1981. Print.

Roberts, David Francis. "Jeshurun." NETBible:. Bible.org, 2006. 09 Nov. 2014. Web. <http:// classic.net.bible.org/dictionary.php?word=Jeshurun>.

Simonsen, Jane E. Making Home Work: Domesticity and Native American Assimilation in the American West, 1860-1920. Chapel Hill: U of North Carolina P, 2006. Print.

Slickpoo, Allen P. Sr. Noon Nee-Me-Poo (We, the Nez Perces): Culture and History of the Nez Perces. Vol. 1. Lapwai, Idaho: Nez Perce Tribe of Idaho, 1973. Print.

Smith, Sidonie, and Julia Watson. Women, Autobiography, Theory: A Reader. Madison: U of Wisconsin P, 1998. Print.

Stanton, Elizabeth Cady, and Susan B. Anthony. "Declaration of Rights of the Women of the United States by the National Woman Suffrage Association, July 4th, 1876." The Selected Papers of 
Elizabeth Cady Stanton and Susan B. Anthony. Volume III. Ed. Anne D. Gordon. New Brunswick, N.J.: Rutgers University Press, 2003, 234-241. Print.

Thomas, David Hurst. Skull Wars Kennewick Man, Archaeology, And The Battle For Native American Identity. New York: Basic Books, 2000. Print.

Tonkovich, Nicole. The Allotment Plot: Alice C. Fletcher, E. Jane Gay, and Nez Perce Survivance. Lincoln : U of Nebraska P, 2012. Print.

---. "Lost in the General Wreckage of the Far West': the Photographs and Writings of Jane Gay." Trading Gazes Euro-American women photographers and Native North Americans, 1880-1940. Ed. Susan Bernardin et al. New Brunswick, N.J.: Rutgers UP, 2003. 33-70. Print.

---. "Parallax, Transit, Transmotion: Reading Race in the Allotment Photographs of E. Jane Gay." MELUS 39 (2014): 66-92. Print.

Willard, Frances E. “The Carlisle Indian School.” The Red Man (February 1889) 6-7. Print.

\section{APPENDIXES}

Photographs

With one exception noted below, all of E. Jane Gay's photographs included in this article are from the Online Open Collections of the Schlesinger Library, Radcliffe Institute, Harvard University.

"Author" (I)

"Photographer" (8)

"Behold the Cook" (227)

“Cook Writes a Letter (154)

“Photographer Fatigued" (293)

"Box Case" (340-41)-four photographs

"Owner of the Lodge" (65)

“Decorating Graves at Lapwai” (235) - two photographs

"Chief Joseph" (236)

"Chief Joseph with Alice C. Fletcher, Gov't Allotting Agent when the Nez Perce Reservation was thrown open. James Stewart kneeling." 1890. ISHS 3771. Reproduced with the permission of the Idaho State Historical Society Library and Archives.

“Retrospect" (451)

“Omaha Madonna" (219)

\section{NOTES}

i. Tonkovich's 2012 book The Allotment Plot offers an in-depth analysis of Alice Fletcher's implementation of the Allotment Act. She also gives a succinct account in her chapter on Gay in 
Trading Gazes ("Lost" 35-36). See also Emily Greenwald's comparative study of the effects of the Allotment policy on the Nez Perce and the Jicarilla Apaches.

ii. Among the documents relating to Gay in the Radcliffe Library is a brief biographical note written by her niece explaining that the two women had attended the same boarding school and had renewed their acquaintance "sometime before 1888" (Dodge 4). Gay's plan to go as "official photographer, her expenses to be part of the Government project" (Dodge 5), apparently did not materialize.

iii. In choosing an Indian word for the title of her book, Gay replicates for her readers the experience of encountering a culture and a people that are quite foreign to her. In a letter to Gay dated 10 November, 1902, her Idaho missionary friend, Kate McBeth explains that "Choup-nit or Choupnit pa lu-is the name given to the Nez Perce by other tribes. L \& C knew them by this name-tried to spell it and made it Choppunish-Pierced Noses" (original underlining). The Nez Perce refer to themselves as Nimiipuu or Nee-me-poo (Slickpoo). Although Gay is in part correcting Lewis and Clark's mistake in her choice of a title for her book, McBeth's informants "insist that the name Chup nit and Nez Perce are misnomer." MS. 4558, Papers of Alice Cunningham Fletcher (1838-1923) and Francis La Flesche (1859-1923). National Anthropological Archives. Transcribed by Nicole Tonkovich, 15 Jan. 2007. I am grateful to Professor Tonkovich for generously sharing this information.

iv. Like much of women's life writing Choup-nit-ki is difficult to classify, since the author is and is not its subject. Smith and Watson point out the wide range of generic possibilities that can be grouped together under the category.

v. Among other honors and accomplishments in the field of Anthropology, Fletcher was a founding member of the American Anthropological Association and had an endowed Chair created for her at the Peabody Museum of Archaeology and Ethnology.

vi. Tonkovich argues that Gays photographs "aided and abetted" Fletcher's work of "establishing the Nez Perce as racialized proto-citizens," although they also "make visible the persistence of Native sovereignty in the face of colonial incursions such as allotment" ("Parallax" 68-69).

vii. E. Jane Gay spent the last years of her life in England where she lived with Dr. Caroline Sturge until her death in 1919.

viii. So far, Choup-nit-ki has mainly been studied for the oblique light it sheds on Alice Fletcher's implementation of the Allotment Act (Tonkovich Allotment; Hoaxie and Mark). Tonkovich and Simonsen's penetrating studies demonstrate the originality of Gay's vision of the West.

ix. Cf. Genette's study on the paratext as threshold.

$\mathbf{x}$. All subsequent quotations are taken from the manuscript, as are the photographs included in this essay thanks to the generosity of the Schlesinger Library, Radcliffe Institute, Harvard University, that has made E. Jane Gay's work available online as part of the Harvard University Open Collections Programme. A list of photographs included here, with the titles and page numbers as they appear in Choup-nit-ki, is appended to this essay.

xi. Emma Gay copied the letters and decorated the manuscript with her illustrations. As is the case with the title page illustrations, many of the subsequent drawings engage in dialogue with the text, in the style of medieval illuminated manuscripts. However, whereas in medieval manuscripts the images often subvert the orthodoxy of the text, Emma Gay's illustrations tend to exert a normative influence. She favors a nostalgic style featuring traditional artifacts and clothing and imitating Native American ledger art. Many of Emma's drawings are stylized versions of the ethnographic images that her aunt made to document Alice Fletcher's work, some of which can be seen online in the Harvard University Open Collections. The drawings contrast with the broader scope of Choup-nit-ki's photographic and literary documentation of the way the Nez Perce were living in the 1890s. Tonkovich's essay, "Parallax, Transit, Transmotion: Reading Race in the Allotment Photographs of E. Jane Gay," describes how the photographs hint at "transmotional" Nez Perce trajectories. 
xii. Smith and Watson offer a succinct account of the ideological implications underpinning the subject in canonical autobiographies: "What we have understood as the autobiographical ' $I$ ' has been an 'I' with a historical attitude-a sign of the Enlightenment subject, unified, rational, coherent, autonomous, free, but also white, male, Western. This subject has been variously called 'the individual' or the 'universal human subject' or the transcendent subject' or 'man.' Cultural attachment to this sovereign 'I' signals an investment in the subject of 'history' and 'progress' for this 'man' is the subject who traveled across the globe, surveyed what he saw, claimed it, organized it, and thereby asserted his superiority over the less civilized 'other' whom he denigrated, exploited, and 'civilized' at once" (27).

xiii. According to Bakhtin, language is dialogic: "there are no 'neutral' words and forms-words and forms that can belong to 'no one'; language has been completely taken over, shot through with intentions and accents. For any individual consciousness living in it, language is not an abstract system of normative forms but rather a concrete heteroglot conception of the world.... Each word tastes of the context and contexts in which it has lived its socially charged life; all words and forms are populated by intentions" (293). Smith and Watson affirm the usefulness of Bakhtin's theory of heteroglossia "for discussions of women's autobiography," since "the autobiographical subject is a subject of the play of voices" (30).

xiv. Commenting on Susan Macgoffin's mid-nineteenth century account of her journey on the Santa Fe Trail, Georgi-Finlay observes: "The positioning of this female narrator within an expansionist discourse is essentially unstable, oscillating between national loyalty and the privileging of personal relations. It is these fissures in some women's western narratives that contain a cultural critique which shatters the complacent, self-contained pose of the anticonquest" (103). Georgi-Finlay also makes reference to the studies which detect ambivalence about American imperialism in accounts by men on the frontier (293 n.5).

xv. In the late nineteenth century Boas published a paper "defending skull shape as a good indicator of deep seated racial differences," although later, after an extensive study of different measurements, he became skeptical about racial classifications (Thomas 104-105).

xvi. Jeshuran means "upright" and is a poetic name for the people of Israel (Roberts).

xvii. Gay was certainly aware of the situation, since the Crofters' Holdings Act, the first legislation to protect the crofters, was passed in 1886.

xviii. Quoting Virginia Woolf, Braidotti insists that women who are "excluded from sociopolitical rights" are "home-less" (253).

xix. This extract appears in the letter published in the April 1890 edition of The Red Man, under the heading "A Brave Woman Allotting Lands to Indians in Idaho: Novel and Interesting Experiences as told by the Companion of Miss Fletcher." In contrast to the extracts selected in Choup-nit-ki, much of that letter relates the women's doings from Alice Fletcher's point of view, using the pronoun "you" as an invitation to readers to share her perspective and her experience. See Tonkovich's commentary on this practice ("Lost" 66). Both Fletcher and Gay published reports of the progress of allotment in The Red Man (Tonkovich Allotment 31-33).

xx. Roman Jakobson analyzes the way personal pronouns and other grammatical "shifters" depend for meaning on the context in which they are uttered-the relation between the speaker and the addressee (132).

xxi. Cathleen Cahill has ably documented the concept of maternal colonialism and its promotion by the Indian Service in the Assimilation era.

xxii. The text probably alludes to Melville's short story, "The Lightning Rod Man."

xxiii. Heteroglossia is one of Bakhtin's terms for the polyvocality of language.

xxiv. Georgi-Findlay remarks this trope in many of the women's frontier narratives she studies, although their West is "nevertheless, still a culturally contested terrain in which the U.S. military presence has a precarious hold, never quite able to guarantee the white women's safety" (133). 
xxv. Gay uses a range of epithets to designate Alice Fletcher, giving an idea of her multiple responsibilities-"the archeological member of our party" (5), "the Allotting Agent" (8), "the ad interim Agent," "the Special Agent" (24), "the Measuring Woman" (171) and "Her Majesty" (vi)." Nevertheless, in spite of this multiplicity, Gay's photographs give a fairly consistent image of Alice Fletcher in the field, consonant with the stability of demeanor that Gay attributes to her companion. Fletcher's conservative dress and her stocky form recall the iconic images of Queen Victoria and suggest the aura of respectability that the monarch cultivated. When it comes to representing herself, however, Gay is far more adventurous.

xxvi. The tantalizing flimsiness of this veiled homoerotic allusion works to energize the sense of the intensity of the women's bonds with each other. Gay's letters are saturated with hints of the teasing, ironic complicity that the two women enjoyed. Simonsen observes that "researchers may have overestimated the nonsexual nature and thus the acceptability of [romantic female] relationships" (116).

xxvii. Georgi-Findlay quotes Wallace Stegner's summary of the archetypal Western fiction: "male freedom and aspiration versus female domesticity, wilderness versus civilization, violence and danger versus the safe and tamed" (Stegner quoted in Georgi-Findlay 6).

xxviii. Amy Kaplan and Jane E. Simonsen have convincingly analyzed the imposition of nineteenth century standards of domesticity as women's contribution to imperial policy.

xxix. The museum at the Tamástslikt Cultural Institute in Oregon gives the tribes' view of contact with the colonizers in an exhibit that features, among other things, the trash left along the Oregon trail.

xxx. Jane Simonsen makes a similar point in suggesting that as the Photographer, "she called attention to gender as performative rather than biological, in opposition to social evolutionary definitions of gender" (119).

xxxi. In studying Fletcher's extensive correspondence Tonkovich discovers her "plural and often inconsistent behaviors," as well as her doubts and frustrations concerning the policy she was implementing (Allotment 202). This nuances Choup-nit-ki's portrait of a more coherent persona. Tonkovich also argues that the various epithets designating Fletcher suggest multiple identities. If this is the case, the photographs work to homogenize the characterization.

xxxii. Simonsen suggests that the readers of the newspaper "may not have known that the Photographer was not male" (119); by extension, they may not have thought of Miss Fletcher's companion as the same person as the Cook.

xxxiii. Besides having her letters published in The Red Man and other newspapers, Gay was the author of a long poem on the Civil War (Tonkovich "Lost" 43). Included among the Jane Gay Dodge Papers is an extract copied from a letter that appeared in the Georgia Telegraph (January 10, 1860) that mentions an "entertainment" performed at "the Misses Gay and Melville's School" in Macon and penned by "one of the accomplished principals." The piece is described as a "little dramatic satire upon 'the strong minded' and 'the woman's rights movement." If this piece is by Gay, its satire would probably have been characteristically double edged.

xxxiv. See Deleuze and Guattari's Introduction to A Thousand Plateaus (6-21), where they contrast rhizomatic and arborescent multiplicities. The arborescent structure is unitary and hierarchical whereas "the rhizome connects any point to any other point, and its traits are not necessarily linked to traits of the same nature.... The rhizome operates by variation, expansion, conquest, capture, offshoots" (21).

$\mathbf{x x x v}$. As Tonkovich suggests, the ambiguous identity of the 'I' can be seen as "a way of refusing the imperial certainty that bankrolled their expeditions" into Nez Perce territory (Tonkovich, "Lost" 35).

xxxvi. Composed by Francis C. Burnand (libretto) and Arthur Sullivan (music), the operetta was first performed in New York on April 14, 1879 (Hischack 95-96). 
xxxvii. Tonkovich explains that the land in question had already been claimed by Mrs. Lily Viles (Allotment 264).

xxxviii. Tonkovich argues that "the academic discipline of anthropology, supported by archives of illicitly appropriated cultural items, posited a theory of progressive development used in the 1870 's and 1880's to justify a federal policy of Native assimilation and extinction" (Allotment 300).

xxxix. As the unofficial member of the expedition, Gay was able to observe the implementation of the Dawes Act with more detachment than Alice Fletcher, who was acting as a government official. Nonetheless, Fletcher's letters to one correspondent back East reveal doubts that she does not express to others, especially not to Gay (Mark 177).

xl. Tonkovich comments on the "layered ironies" in Gay's description of this episode ("Lost" 58). xli. In Tonkovich's analysis, the figure of the Cook is "the least enlightened member of the party" ("Lost" 61). For this reason, she argues that the mouse episode "cannot be construed as a direct critique of Fletcher's actions" ("Lost" 63). In my own reading, Gay distances all her personae through irony, but that does not prevent them from vehicling critiques of others.

xlii. Gay's photograph, “Chief Joseph with Alice C. Fletcher, Gov't Allotting Agent when the Nez Perce Reservation was thrown open. James Stuart kneeling" (ISHS 3771), is reproduced with the permission of the Idaho State Historical Society Library and Archives.

xliii. Tonkovich discusses Stuart's work with Fletcher and his subsequent role in tribal politics in "Parallax."

xliv. See Nina Baym's discussion of women writers of the Pacific Northwest (41-63).

xlv. I am thinking of works like John Charles Frémont's Mémoirs of My Life or John Wesley Powell's The Exploration of the Colorado River and Its Canyons.

xlvi. Judith Butler's critique of the production of gendered subjectivity starts from Foucault's claim "that juridical systems of power produce the subjects they subsequently come to represent" (Butler 2). Her book troubles the categories of gender and identity by exploring the ways in which they are constructed.

\section{ABSTRACTS}

Due to its unusual publishing history, E. Jane Gay's Choup-nit-ki: With the Nez Percés has not received the critical attention it deserves. Through the book's photographs and text, Gay stages a migratory, polyvocal narrator who rejects the unitary identity that establishes both the writer's and the colonizer's authority. This article studies textual features such as shifting focalization, the splitting of the writing subject into multiple personae, and the humor extracted from social contradictions to show how Gay's book both cites and challenges nineteenth century conventions governing genre and gender. Contemporary theory (Deleuze and Guattari, Braidotti, Butler) provides concepts that can aid our appreciation of the text's originality. Gay's self-presentation cracks the restrictive nineteenth century mold of femininity and liberates the subject, even as, ironically, the author collaborates in the project of imposing on the Nez Perce the constraints legislated through the Dawes Act. Gay's book illustrates the author's ambivalence about the Allotment policy that attempted to end tribal organization on the Nez Perce reservation. 
INDEX

Mots-clés: Alice Fletcher, Chief Joseph, E. Jane Gay, Félix Guattari, Gilles Deleuze, Nicole Tonkovich, Rosi Braidotti

Keywords: allotment, American West, assimilation, autobiography, Dawes Act, gender, Idaho, identity, imperialism, letters, Nez Perce, nomadic writing, women

\section{AUTHOR}

\section{WENDY HARDING}

Université de Toulouse Jean Jaurès, CAS 